Isabel Cristina Pereira

Aspectos Fisiológicos e Ecológicos da Estivação em

Pleurodema diplolistris (LeiuperidaelAnura)

São Paulo

2009 
Isabel Cristina Pereira

\section{Aspectos Fisiológicos e Ecológicos da Estivação em Pleurodema diplolistris (Leiuperidae/Anura)}

Dissertação apresentada ao Instituto de Biociências da Universidade de São Paulo, para a obtenção de Título de Mestre em Ciências, na Área de Fisiologia.

Orientador: Prof. Dr. Carlos Arturo Navas Iannini

São Paulo

2009 
Pereira, Isabel Cristina

Aspectos Fisiológicos e Ecológicos da

Estivação em Pleurodema diplolistris

(Leiuperidae/Anura)

Número de páginas: 70

Dissertação (Mestrado) - Instituto de

Biociências da Universidade de São Paulo.

Departamento de Fisiologia.

Palavras-chave: 1. Estivação 2.

Metabolismo energético 3. Anfíbios anuros I.

Universidade de São Paulo. Instituto de

Biociências. Departamento de Fisiologia.

\section{Comissão Julgadora:}

Prof(a). Dr(a).

$\operatorname{Prof}(a) . \operatorname{Dr}(a)$.

Prof. Dr. Carlos Arturo Navas lannini

Orientador 
Ao meu pai, Zeca, minha mãe, Angelita, e minha irmã, Sandra ...com muito amor! 


\section{AGRADECIMENTOS}

Agradeço primeiramente a Deus por ter me dado forças para chegar até aqui. Por ter me guiado e sustentado durante essa trajetória.

Agradeço ao Professor Doutor Carlos Navas pela dedicação, apoio e por todas as oportunidades que me ofereceu. Por ter acreditado no meu trabalho e me orientado.

Agradeço ao Professor Doutor José Eduardo de Carvalho por ter me ajudado e orientado com muita paciência em todos os momentos.

Agradeço ao Professores Doutor Fernando Ribeiro Gomes e à Dra Andréa Maria Garrido dos Santos por todo o apoio e ajuda durante a execução deste trabalho. Às Professoras Doutoras Renata Guimarães, Silva Cristina Ribeiro de Souza e ao Professor Doutor José Guilherme Chauí-Berlink por ajudarem-me sempre com muita paciência a solucionar todas as minhas dúvidas.

Agradeço ao Professor Doutor Carlos Jared por apoiar-me na execução deste trabalho e apresentar-me o local e os companheiros da Fazenda São Miguel, sem os quais a execução detse trabalho não seria possível. Agradeço aos companheiros como o Sr. Francisco de Assis Rodrigues, administrador da Fazenda, e sua esposa, Neci, que acolheram-me como parte da família e ajudaram-me em tudo que precisei. Serei eternamente grata a esta família que aprendi a amar durante estes anos. Agradeço também ao Roque, Junior, Moacir e a todos os moradores da fazenda que, de alguma forma, contribuíram para a realização deste trabalho.

Agradeço a todos os meus colegas de laboratório, por estarem sempre ajudandome em campo, no laboratório, dando-me dicas, pela festa surpresa e pelas risadas que demos juntos. Agradeço, em especial, à minha assessora de Português, Meirielen por toda ajuda e amizade durante estes anos. Agradeço à secretária Gisele Ortoli pela assistência, compreensão e pela amizade que nasceu ao longo desses anos.

Agradeço à Fundação de Amparo à Pesquisa do Estado de São Paulo (FAPESP), pelo apoio financeiro (Processo $n^{\circ}$ 06/52760-5) e acessória científica, pelas sugestões e críticas que ajudaram na melhoria deste trabalho. Também agradeço ao Instituto do Meio Ambiente e dos Recursos Naturais Renováveis (IBAMA) pela autorização de coleta de animais nos locais específicos.

Finalmente, quero agradecer à minha família. Agradeço muito à minha mãe, Angelita por ter costurado durante muitas madrugadas para me ajudar, ao meu pai, Zeca, por ter passado tanto tempo sem dormir para auxiliar-me e agradeço também a minha irmã, Sandra, pelo auxílio. Agradeço muito por terem acreditado em mim e apoiado-me sempre. 


\section{ÍNDICE}

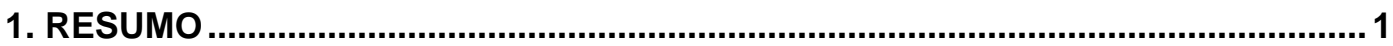

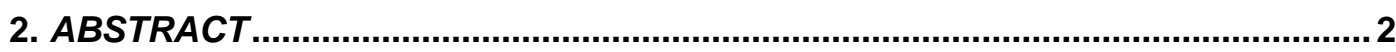

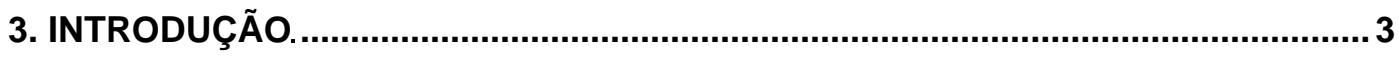

3.1. Desafios comportamentais e ecofisiológicos de anuros estivadores ....................... 3

3.2. Princípios gerais sobre os ajustes metabólicos em anuros estivadores ................ 7

3.3. A estivação em anuros da Caatinga Brasileira................................................... 11

3.4. Por que estudar Pleurodema diplolistris? ..................................................... 13

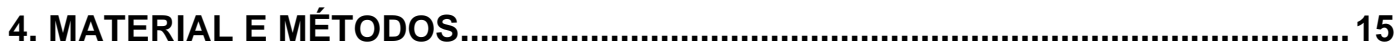

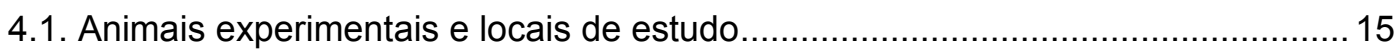

4.2. Caracterização microclimática dos locais de coleta ......................................... 16

4.3. Medida de taxa metabólica.......................................................................... 17

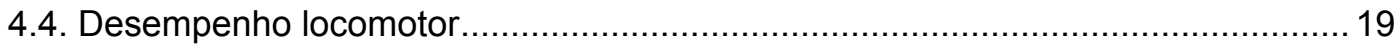

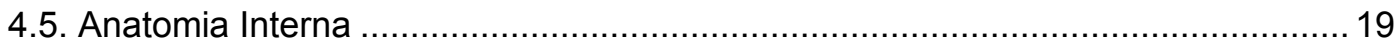

4.6. Tratamento das amostras de tecido ...................................................... 19

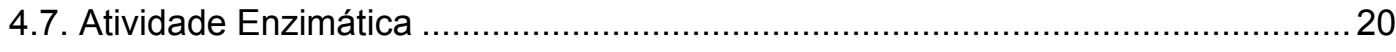

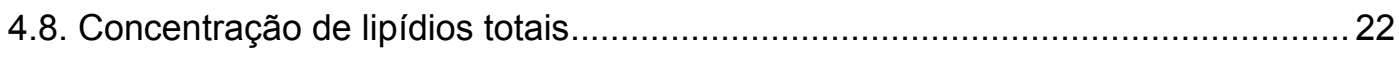

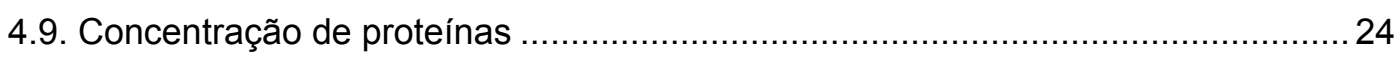

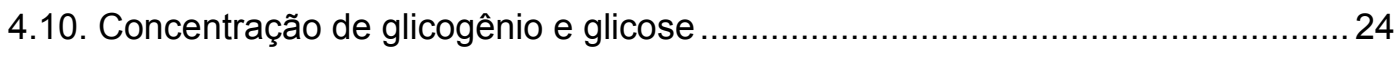

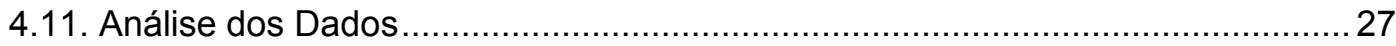

5. RESULTADOS

5.1. Caracterização do microhábitat de estivação de $P$. diplolistris na área de estudo 28

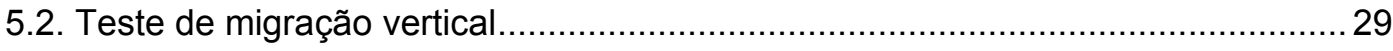

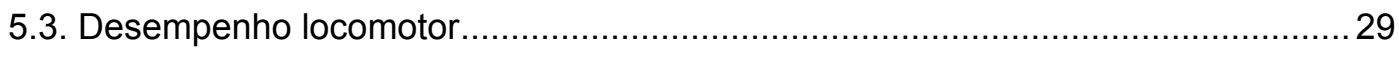

5.4. Taxa metabólica de repouso e durante o exercício ............................................... 29

5.5. Concentração de substratos energéticos ...................................................... 29

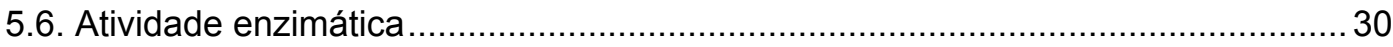

5.7. História natural e observações de campo …....................................................... 31

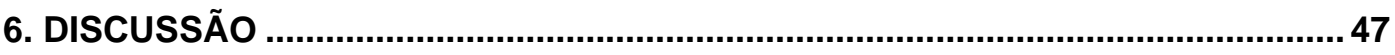

6.1. Características do microhábitat e do comportamento de $P$. diplolistris ................4 47

6.2. Ajustes metabólicos na estivação de Pleurodema diplolistris .............................. 51

6.2.1. Desempenho locomotor e taxa metabólica............................................ 51

6.2.2. Reservas energéticas e atividade enzimática........................................ 54

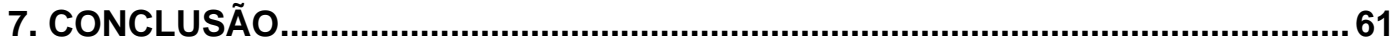

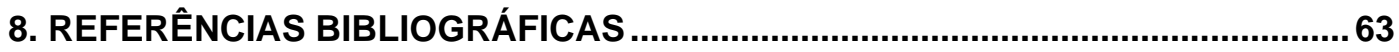




\section{RESUMO}

As Caatingas formam um domínio morfoclimático exclusivo do Brasil, caracterizado por índices pluviométricos baixos e imprevisíveis, além de temperaturas elevadas. Em certos grupos de anuros, a sobrevivência durante o período de estiagem está associada ao comportamento de estivação, um conjunto de alterações observadas que permitem a sobrevivência em condições áridas. Os sapos Pleurodema diplolistris (Leiuperidae/Anura) são encontrados enterrados na Caatinga na fase de seca e evidências indicam que esses indivíduos apresentam menor atividade durante essa fase, apesar de exibirem certa migração vertical no substrato acompanhando a diminuição da umidade deste. O padrão de alterações nas concentrações de lipídeos e glicogênio em diferentes amostras de tecido corrobora a hipótese de diminuição do metabolismo durante o período de estiagem. No músculo dos membros posteriores, a manutenção dos níveis protéicos próximos aos valores observados em animais ativos coletados durante a fase de chuvas, sugere a preservação da capacidade funcional do tecido mesmo nos meses mais adversos. A capacidade aeróbia esteve reduzida durante a fase seca em comparação a fase de atividade e a capacidade glicolítica anaeróbia mantevese preservada. Verificou-se também um gradiente de umidade vertical no abrigo, evidenciando uma diminuição da umidade a partir da superfície, ao longo da fase de estiagem, o que poderia corroborar a migração vertical. 


\section{ABSTRACT}

Caatinga is a Brazilian semi-arid bioma that is characterized by the dryness and the unpredictable seasonality of rains. In some anurans the survive is associate with aestivation, a set of strategies for survival in arid conditions. Pleurodema diplolistris frogs (Leiuperidae/Anura) are found buried in the Caatinga during the dry time. Evidences indicate that individuals of this group have lower activity during this phase, although some exhibit vertical migration in the substrate following the decrease in the moisture of it. The pattern of changes in concentrations of lipids and glycogen in different samples of tissue supports the hypothesis of a reduction of metabolism during the drought. In the muscle of the hindquarters, the maintenance of protein levels close to those values observed in active animals collected during the rainy season, suggests the preservation of functional capacity of the tissue even in most adverse months. The aerobic capacity was reduced during the drought compared to the period of anaerobic glycolytic activity and the capacity has remained preserved. It was also found a gradient of moisture under the vertical, showing a decrease in moisture from the surface, during the drought, which could corroborate the vertical migration. 


\section{INTRODUÇÃO.}

\subsection{Desafios comportamentais e ecofisiológicos de anuros estivadores}

Em anfíbios do semi-árido, ciclos anuais de seca e chuva determinam a fase de atividade reprodutiva, que é estritamente dependente de condições hídricas apropriadas (ABE, 1995; TRACY et al., 2007). Os anfíbios típicos de regiões áridas costumam ser ativos apenas dois ou três meses no ano, mas há relatos para Ramanella montana (Microhylidae) reportando a atividade por até seis meses (KRISHNA et al., 2004). A temperatura parece exercer um papel importante para os ciclos anuais em anuros, visto que os animais não respondem à presença de chuva em condições frias, além de não emergirem depois de uma chuva de verão se a temperatura for muito alta (PINTER et al., 1992). Entretanto, a estivação não é necessariamente desencadeada apenas por fatores ambientais, pois mesmo quando expostos a claro constante, indivíduos de Scaphiopus couchii entram em dormência e espontaneamente, deixam de se alimentar na fase em que estariam em estivação (PINTER et al., 1992). Isso sugere a existência de ritmos endógenos intrínsecos associados a ciclos metabólicos (PINTER et al., 1992).

A seleção de microhábitats é essencial para a sobrevivência de muitos anuros estivadores, mas certas espécies estivam em microhábitats que não parecem minimizar os desafios fisiológicos relacionados à potencial perda de água ou a exposição a temperaturas extremas durante a estivação (MAYHEW, 1965; KoBELt et al., 1995). Contudo, na maior parte das espécies estivadoras o hábito de se enterrar é importante para minimizar os efeitos causados pela seca e altas temperaturas a que estariam sujeitos na superfície (CARTLEDGE et al., 2006a; Bentley, 1966; ВоOth, 2006; MAYHEW, 1965; SeYmour, 1973a). A 
combinação entre o hábito de se enterrar e a diminuição da taxa metabólica durante a estivação leva os animais a pouparem seus estoques energéticos e reduzirem a perda de água (WITHERS \& THOMPSON, 2000).

A estivação de anuros em microhábitats fossoriais envolve dois tipos de estratégias: (1) animais que se enterram a grandes profundidades em solo arenoso e de fácil escavação ou (2) animais que formam canais e ficam a poucos centímetros da superfície, em solo argiloso e de difícil escavação (BоOтH, 2006). A profundidade à que os indivíduos se enterram pode variar entre 2 e 8cm, como no caso de Cyclorana australis (TRACY et al., 2007), a até mais de $1 \mathrm{~m}$, com visto em Pleurodema diplolistris, Proceratophrys e Physalaemus sp. (NAVAs et al., 2004).

A estivação de algumas espécies de anuros está associada à formação de um casulo que aparentemente reduz a taxa de perda de água. Contudo, mesmo espécies que usualmente formam casulos durante a estivação, podem não chegar a formá-los quando a disponibilidade de água no solo é relativamente alta (MCCLANAHAN et al., 1967, 1976). Os anuros formadores de casulo assumem uma posição típica de conservação de água e acumulam camadas de tecido derivado do estrato córneo da pele em número que pode variar consideravelmente entre espécies (WITHERS \& THOMPSON, 2000). Em indivíduos de Cyclorana australis e Cyclorana cultripes, os casulos possuem em média 33 camadas, formadas em 48 dias após a entrada em dormência, sendo estas translúcidas, porém eficientes ao reduzir a perda de água por evaporação em aproximadamente 15 vezes (WITHERS \& THOMPSON, 2000). Já no caso específico de Lepidobatrachus llanensis, o casulo é contínuo ao longo 
do corpo, sendo inexistente apenas na região das narinas externas, podendo até ser removido intacto (MCCLANAHAN, 1972).

A presença de casulo em anuros que estivam em ambientes fossoriais de forma alguma constitui uma regra universal. Sapos do deserto da espécie Scaphiopus couchii, por exemplo, são estivadores típicos que não formam casulos (MCCLANAHAN, 1967). Outras espécies com hábitos fossoriais, como os gêneros Pleurodema, Physalaemus e Proceratophrys, também não formam casulos. Os anuros estivadores que não formam casulo estão sujeitos a um aumento na vascularização periférica, o que aumenta a capacidade de absorção quando o potencial osmótico é favorável, pois o corpo mantém contato com o solo promovendo uma captação oportunista de água (NAVAS et al., 2004; CARTLEdge et al., 2006b). Nestes casos, o gradiente osmótico favorável é garantido pelo acúmulo, principalmente, de uréia (SHOEMAKER, 1964). Assim, os animais podem aumentar a concentração osmótica dos fluidos corpóreos, reduzindo seu próprio potencial hídrico em solos mais áridos (SCHMUCK \& LINSENMIR at al, 1997).

Certas características do solo, como o potencial hídrico e temperatura, podem influenciar o sucesso de sua utilização como abrigo por anuros, pois essas características influenciam diretamente a taxa de hidratação ou desidratação do animal (SEYMOUR, 1973c). A granulosidade do solo é um dos principais fatores que influenciam na disponibilidade de água (MCCLANAHAN, 1972). Em sapos Scaphiopus couchii, observou-se que animais enterrados em solos com baixos potenciais hídricos possuíam uma concentração do plasma maior que animais enterrados em solos com alto potencial hídrico, o que mostra uma relação direta entre a disponibilidade de água no solo e o estado 
fisiológico do animal (MCCLANAHAN, 1972). A taxa na qual a uréia é produzida e retida em certas espécies de anfíbios parece ser inversamente proporcional ao potencial hídrico do solo. (McClANAHAN, 1967 e 1972; SHOEMAKER et al., 1969). O fato é que anfíbios de ambientes xéricos podem produzir e estocar mais uréia do que os de ambientes aquáticos. Sapos da espécie $S$. couchii, por exemplo, exibem um aumento da concentração de uréia e eletrólitos no plasma durante a seca, mantendo um gradiente osmótico favorável que evita a perda de água para o solo (SHOEMAKER et al., 1969). Algo similar foi observado em Leptodactylus, que tem uma diminuição na osmolaridade do plasma e da urina durante a fase de estivação (ABE \& GARCIA, 1990).

Cabe ainda salientar que a inatividade durante a fase de estivação em anuros poderia levar a alterações na composição estrutural dos tecidos, como a atrofia muscular, caracterizada pela redução da área transversal do músculo e comprometimento da função locomotora (SYMONDS et al., 2007b). Assim, a ausência de atividade per se constitui um desafio fisiológico para anuros estivadores. Entretanto, experimentos conduzidos in vitro com sapos Cyclorana alboguttata demonstraram que a contração isométrica e à tolerância a fadiga do músculo gastrocnêmio é bastante preservada durante os três primeiros meses de estivação, evidenciando a manutenção da funcionalidade muscular mesmo em condições de bastante imobilidade (HUDSON \& FRANKLIN, 2002a). Apesar dos músculos aeróbios serem aparentemente mais suscetíveis à atrofia muscular que músculos glicolíticos durante a estivação (SYMONDS et al., 2007a), indivíduos de Cyclorana alboguttata parecem ser capazes de minimizar a atrofia muscular durante a fase de dormência. A inibição dos danos causados parece estar ligada à diminuição do consumo de oxigênio e, consequentemente 
da produção de espécies reativas de oxigênio, que levariam a uma degradação generalizada de muitas proteínas musculares (HUDSON \& FRANKLIN, 2002b). É provável que um dos grandes desafios para a sobrevivência em condições adversas seja, na verdade, a fase de recuperação e saída do estado inativo (HOCHACHKA \& GUPPY, 1987).

\subsection{Princípios gerais sobre os ajustes metabólicos em anuros estivadores}

Muitos organismos são capazes de minimizar a ciclagem energética frente a condições adversas do ambiente, ingressando em um estado hipometabólico usualmente chamado de depressão metabólica (GUPPY, 2004). Este fenômeno é caracterizado por uma diminuição da taxa metabólica e tem sido reportado em vários filos em resposta a estresses como temperaturas muito elevadas ou extremamente baixas, anóxia e escassez de recursos tróficos e hídricos (GUPPY et al., 1994; GUPPY \& WITHERS, 1999; HAND \& HARDEWING, 1996; STOREY \& STOREY, 2004). A ocorrência de hipometabolismo em animais é estudada há pelo menos trezentos anos, sendo um dos primeiros relatos de 1702, no qual Antony van Leeuwenhoek observou rotíferas que, uma vez dessecadas, entravam em estado completamente inativo e, quando hidratadas, retomavam a atividade (ver TUNNACLIFFE \& LAPINSKI, 2003 como referência). Desde então, outros diversos modelos de invertebrados e vertebrados vêm sendo investigados com respeito a este aspecto da biologia e do modo de vida (GUPPY \& WITHERS, 1999). Neste sentido, muitos avanços têm sido obtidos em grupos mais estudados, como no caso de artêmias e outros invertebrados, pequenos mamíferos, tartarugas, peixes e anfíbios anuros. 
Em anfíbios anuros a depressão metabólica está associada ao fenômeno de estivação (ABE, 1995; StOREY \& StOREY, 1990; PINTER et al., 1992), um fenômeno complexo que envolve diversos ajustes metabólicos que adéquam as funções do organismo aos meses de dormência. Esses ajustes incluem maior dependência da oxidação de reservas de lipídeos (FUERY et. al., 1998) e uma drástica redução na respiração cutânea com consequente redução da perda evaporativa de água (GUPPY \& WITHERS, 1999; ABE, 1995; GuPPY, et. al., 1994; HoCHACHKA \& GUPPY, 1987). Entretanto, a diminuição do metabolismo aeróbio é um dos eventos mais marcantes na transição do estado ativo para o estado hipometabólico característico da estivação nestes animais. Na rã Neobatrachus wilsmorei (Limnodynastidae), por exemplo, o consumo de oxigênio é reduzido de 80 a $85 \%$ durante a fase de inatividade, quando comparado aos valores observados durante o estado normal de atividade nos meses de chuva (HAND \& HARDEWING, 1996). Outras espécies de anuros como Bufo alvarius (Bufonidae), Ceratophrys ornata (Ceratophryidae) e Pyxicephalus adspersus (Pyxicephalidae) apresentam uma redução de cerca de $20 \%$ da taxa metabólica aeróbia quando induzidos à estivação (BASTOS \& ABE, 1998; SECOR, 2005).

A depressão metabólica em anuros está associada a mudanças no padrão de uso dos substratos energéticos. Durante a estivação do sapo Scaphiopus couchii (Scaphiopodidae), por exemplo, os estoques hepáticos de glicogênio são amplamente preservados durante a fase hipometabólica, o que sugere uma baixa utilização de carboidratos durante esta fase (STOREY \& StOREY, 1990). Estudos conduzidos com Neobratrachus pelobatoides (Limnodynastidae), uma espécie de sapo estivador do deserto australiano, 
indicam uma diminuição de $67 \%$ da síntese de proteínas durante a estivação, evidenciando a redução generalizada do metabolismo energético (FLANIGAN et al., 1991). Dessa forma, os ajustes específicos sobre as vias de metabolização de substratos energéticos modulam a mobilização desses compostos de modo adequado à demanda dos tecidos, havendo uma íntima relação com a modulação dos processos que produzem e utilizam ATP (PINTER et. al., 1992, Guppy et al, 1994).

Um outro tipo de ajuste metabólico associado à estivação é o acúmulo prévio de reservas energéticas, as quais parecem sustentar não somente a fase depressiva, mas também a retomada da atividade (PINTER et. al., 1992; StOREY \& StOREY, 1990; SouzA et. al., 2004). Estes processos são particularmente importantes no caso de anfíbios anuros de ambientes semiáridos que exibem um comportamento reprodutivo oportunista e explosivo nos primeiros dias de chuva (PINDER et. al., 1992). Nos sapos Scaphiopus couchii, a ciclagem sazonal de lipídeos desempenha um importante papel durante a reprodução, não somente para a formação de ovos nas fêmeas, mas também para a manutenção da atividade vocal nos machos (CowAN et al., 2000; WELLS, 2001). Essa preparação para a reprodução inclui tanto ovogênese quanto espermatogênese, processos estes que podem ser afetados pelo período de estiagem (RYSER, 1989). Em indivíduos de Rana temporaria, por exemplo, o prolongamento experimental desse período diminui a produção de gametas (JøRGENSEN, 1992). Além disso, o sucesso reprodutivo nesta espécie depende diretamente da manutenção dos níveis protéicos durante a fase de reprodução (PINDER et. al., 1992; GUPPY et. al., 1994). 
Uma importante reserva energética nos vertebrados é, sem dúvida, o estoque de lipídeos na forma de corpos gordurosos abdominais, subepiteliais e associados aos tecidos hepático e muscular (Duellman \& TRUeB, 1986). Contudo, poucas espécies de anuros apresentam corpos de gordura abdominal durante a fase adulta. Algumas exceções parecem ser espécies que exibem depressão metabólica sazonal (MCCLANAHAN, 1967) ou que são particularmente ativas vocalmente (CARVALHO et al., 2008). Em Scaphiopus couchii, por exemplo, a entrada em dormência ocorre em condições onde 4,5\% da massa corpórea dos animais é composta por lipídeos, mas na retomada da atividade resta pouco menos de 1\% do conteúdo anterior (SEYMOUR, 1973a). Para essa espécie, o orçamento energético durante a estivação é proveniente, em sua maior parte pela oxidação de ácidos graxos.

Em diversos outros modelos de depressão metabólica, a diminuição da síntese protéica é um dos principais aspectos que parece diminuir o consumo energético no estado inativo (HAND \& HARDEWING, 1996). Este é provavelmente um evento recorrente em anuros estivadores, o que envolveria um controle sobre os processos de transcrição e tradução nas células (CowAN et al., 2000; PAKAY et al., 2003; StOREY \& StOREY, 2004). Este controle envolve a fosforização reversível de proteínas, particularmente aquelas que atuam em vias do catabolismo de carboidratos, como a glicólise (STOREY, 1990). Uma alta proporção de formas defosforiladas das enzimas piruvato quinase e fosfofrutoquinase em músculos esqueléticos de $S$. couchii durante a fase de estivação sugere uma depressão da atividade da via glicolítica (COWAN \& STOREY, 1999). Assim, a redução da atividade de enzimas da via glicolítica parece ocorrer de modo coordenado com a supressão de outros processos 
metabólicos, havendo um balanço nas células entre as taxas de produção e consumo de ATP (COWAN \& StOREy, 1999; StOREy \& StOREY, 2004). A síntese de proteínas seria amplamente retomada na fase pós-depressiva que acompanha a energética da estivação em anuros (DUELLMAN \& TRUEB, 1986). Lipídeos e carboidratos, então, parecem ser os mais importantes substratos energéticos em anuros, sendo que a quantidade de proteínas é relativamente conservada durante a estivação (PAKAY et. al., 2003; CoWAN et. al., 2000).

\subsection{A estivação em anuros da Caatinga Brasileira}

A Caatinga forma um domínio morfoclimático exclusivo do Brasil (AB'SABER, 1974), ocupando uma área de aproximadamente $800.000 \mathrm{Km}^{2}$, o correspondente a quase $10 \%$ do território nacional, caracterizado por índices pluviométricos baixos, ventos fortes e secos, além de temperaturas elevadas (Souza ReIS, 1976; Fernandes, 1999). Por isso, a Caatinga tem sido vista como um típico ambiente semi-árido, com longos meses de estiagem. O nome Caatinga tem origem Tupi-Guarani e significa floresta esbranquiçada, o que descreve o aspecto do ambiente durante a estação seca (ROMARIZ, 1996). A herpetofauna da Caatinga é relativamente bem conhecida, e lá são encontradas pelo menos 48 espécies de anfíbios distribuídas entre as famílias: Bufanidae, Hylidae, Leuperidae, Microhylidae, Phyllomedusidae, Pipidae, Pseudidae, Caecilidae e Thyphlonectidae (RODRIGUES, 2003).

Determinadas espécies de anuros que se mantêm em atividade durante os meses de estiagem nas Caatingas, adotam estratégias alternativas para evitar a perda excessiva de água nesta fase. A rã Corythomantis greeningi, possui a pele da cabeça co-ossificada, o que lhe confere proteção quando 
dentro de um abrigo e auxilia secundariamente na economia de água (JARED et al., 2005). Sapos Rhinella jimi mantêm suas atividades mesmo durante a seca, fato que poderia guardar relação com a camada epitelial de grânulos de cálcio (Toledo \& JARED, 1993). Outras espécies pertencentes aos gêneros Pleurodema, Physalaemus, Proceratophrys e Ceratophrys já foram encontradas enterradas a grandes profundidades em leitos secos de rios perenes na região das Caatingas (JARED, C. e NAVAS, C. comunicação pessoal). Entretanto, para se entender a magnitude do desafio fisiológico associado à estivação de anuros na Caatinga, é importante conhecer os valores de algumas variáveis físicas do solo como temperatura, quantidade de água e concentração de gases respiratórios, que podem variar de acordo com o tipo de solo.

Cabe também mencionar que apesar do conhecimento existente sobre a estivação em anfíbios anuros e outros vertebrados ectotérmicos, ainda não são claros os mecanismos utilizados por estes animais para lidarem com a imprevisibilidade típica da Caatinga onde as chuvas podem não ocorrer durante o ano, ou ocorrer em quantidades incompatíveis com a reprodução. O comportamento de alguns organismos dessa região, como é o caso de indivíduos de Pleurodema diplolistris (Anura/Leupidae), merece atenção detalhada, pois parece tratar-se de um modo atípico de estivação associada à escassez de água durante a estiagem. Os indivíduos dessa espécie, assim como outros já vistos na Caatinga (NAVAS et al., 2004), enterram-se em profundidades que podem ultrapassar $1 \mathrm{~m}$ e surgem rapidamente na superfície do solo após as primeiras chuvas. 


\subsection{Por que estudar Pleurodema diplolistris?}

Indivíduos de Pleurodema diplolistris são encontrados em diversas localidades na região do semi-árido brasileiro, mas também em regiões próximas ao litoral (HöDL, 1992). A espécie também ocorre nas dunas próximas ao Rio São Francisco (Bahia), onde aparentemente forrageiam apenas nas noites de chuva (SANTOS et al., 2003). Contudo, a espécie não é endêmica da Caatinga, ocorrendo em muitos outros ambientes como matas e restingas. Essa diversidade converte a espécie em um modelo ideal para estudos comparativos e para se estudar o papel da plasticidade fisiológica no contexto da extensão da distribuição de aspectos de anuros.

Outro aspecto muito marcante com relação ao comportamento de estivação de $P$. diplolistris é proveniente de observações preliminares a este estudo. Os animais desta espécie, ao terem sua estivação interrompida, retomam rapidamente ao estado de alerta, exibindo um comportamento completamente diferente daquele proposto para os casos que têm sido descritos na literatura como típicos da estivação de anuros (ver ST-PIERRE \& BOUTILIER, 2001). Assim, as observações realizadas no campo com esta espécie sugerem um estado dormente no qual certa funcionalidade dos tecidos é mantida, junto com uma apropriada percepção sensorial. Essas observações permitiram postular a hipótese de que uma possível associação ecológica do estado fisiológico acima descrito seria uma eventual migração vertical. Tal migração poderia ser e associada à busca de microhábitats com maior disponibilidade de água. No contexto das observações acima citadas este estudo foi elaborado para testar a hipótese de que indivíduos de $P$. diplolistris passam por ajustes metabólicos importantes durante a fase de estiagem e que 
tais ajustes são compatíveis com a manutenção de certa atividade locomotora associada a migração vertical acompanhando o nível do lençol freático depois de terminada a temporada de chuvas.

Para testar as hipóteses acima citadas, foram realizados acompanhamentos das características físicas do microhábitat usado para a estivação ao longo de gradientes de profundidade. Nesse contexto, focalizamos em variáveis como umidade relativa e temperatura do solo, bem como a concentração de oxigênio. Com relação a fisiologia, foi traçado o perfil metabólico e energético dos animais através de medidas sobre a taxa metabólica de repouso e de atividade de animais coletados nas estações seca e chuvosa. Combinado a isso, foram feitas medidas de cunho organismal sobre o desempenho locomotor nas duas fases marcantes do ciclo desses animais. Foram ainda analisadas as concentrações de substratos energéticos (lipídeos, carboidratos e proteínas) em tecidos de maior importância metabólica, como também estimativas sobre a capacidade metabólica das vias aeróbias e glicolítica através de medidas da atividade máxima de enzimas mais representativas. 


\section{MATERIAL E MÉTODOS}

\subsection{Animais experimentais e locais de estudo}

Este estudo utilizou 66 machos de Pleurodema diplolistris (Leiuperidae/Anura) (Figura 1a) coletados na Fazenda São Miguel, município de Angicos, Estado do Rio Grande do Norte (5³0’43”S. 36³6’18”W) com autorização do IBAMA (02010.003380/04-82 e 14836-1). Os animais foram coletados em dezembro de 2005, setembro de 2006 e abril de 2007. As estações foram denominadas respectivamente de: 1) Possível emergência em um ano atípico (PEAA), no qual não houve estação de chuvas bem definida. Nesse ano obtivemos apenas informações informais sobre a pluviosidade dessa estação, não sabendo exatamente a quanto tempo esses animais estavam enterrados; 2) Seca, nessa estação foram coletados animais após 6 meses da última chuva; 3) Chuva, os animais dessa estação foram coletados quando estavam saindo de seus abrigos para a reprodução, antes de se alimentarem, em um ano que foram confirmadas chuvas compatíveis com a reprodução dos animais. Indivíduos coletados pesaram em média 3,51 \pm 0,11 gramas (média \pm erro padrão) e mediram 3,03 $\pm 0,55 \mathrm{~cm}$ (média \pm erro padrão) de comprimento rostro-cloacal.

Indivíduos da espécie $P$. diplolistris exibem um comportamento reprodutivo sazonal, sendo encontrados em grandes quantidades em poças temporárias (Figura 1b) durante as primeiras chuvas e forrageando no restante da temporada de chuvas (Figura 1c). Durante a estação seca os indivíduos estivam e podem ser coletados enterrados (Figura 2a) no leito do Rio Sobradinho em profundidades que variaram de 40 a $180 \mathrm{~cm}$. Assim, para coletar indivíduos estivando, uma fração do leito do rio definida em estudos 
anteriores foi cuidadosamente escavada. Neste local (Figura 2b) havia uma antiga cacimba (local onde o nível de água subterrânea é mais raso e os moradores locais cavam a procura de água limpa), conhecida como Cacimba do Garajau. As coletas envolveram a escavação de três buracos de aproximadamente $90 \mathrm{~cm}$ de diâmetro e $150 \mathrm{~cm}$ de profundidade. Os animais representantes da estação chuvosa foram coletados no inicio das chuvas fortes, logo após a fase de estiagem na Caatinga, quando os indivíduos emergem de seus abrigos, especialmente nos locais onde os rios começam a encher, formando as primeiras poças sobre o solo ou em meio às pedras. Os animais começam a se reproduzir explosivamente, às centenas espalhados pelos corpos de água (Figura 2c). Em uma única noite foi possível observar inúmeros animais vocalizando a taxas bastante elevadas, em um trinado agudo e contínuo (HÖDL, 1992).

\subsection{Caracterização microclimática dos locais de coleta}

Foram utilizados carregadores de dados $\mathrm{HOBO}^{\circledR}$ (Onset computers, Pocasset, MA, USA) para gravar dados de umidade e temperatura ambiental em microhábitats de $P$. diplolistris de cada fase do ciclo sazonal. O potencial para desidratação de anuros típicos nesses microhábitats foi estimado a partir de modelos de ágar confeccionados no tamanho natural de Pleurodema diplolistris (aproximadamente $3,5 \mathrm{~g}$ ) colocados em recipientes plásticos totalmente vazados utilizados apenas para a identificação do modelo (de acordo com NAVAS e ARAÚJO, 2000), não impedindo o fluxo hídrico entre o ambiente e o modelo. Esses modelos foram enterrados em várias profundidades no mesmo local onde os espécimes foram coletados, e ficaram 
em contato com o solo por 72 horas. Após essa fase, os modelos foram pesados novamente. Através da diferença de massas dos modelos pode ser estimada a perda de água de anuros hipotéticos com a pele totalmente permeável.

A concentração de oxigênio no solo em diferentes profundidades foi medida utilizando seringas de $60 \mathrm{~mL}$ ligadas a válvulas de 3 vias mantidas abertas e enterradas a 25, 50,75, 100, 125 e 150cm a partir da superfície. Após 93 dias, estas foram retiradas, imediatamente lacradas e levadas a outro local de trabalho distante $3 \mathrm{~km}$ para a medida da concentração de oxigênio. Para isso foi utilizado um analisador de gases PA-1 (Sable System) ligado a uma bomba (PP-2 Dual Pump) e um fluxímetro (Matheson). Os conteúdos das seringas foram injetados individualmente no sistema e, a partir da deflexão no sinal gerado pelo analisador de gases, foi calculado o teor de oxigênio nas amostras de ar de diferentes profundidades, semelhante ao procedimento utilizado para medida da taxa metabólica de repouso (ver a seguir). Para cada profundidade foram enterradas 07 seringas. Essa medida não leva em conta os efeitos da eventual demanda localizada de oxigênio produzida por anuros, nem os efeitos sobre a condutividade derivada da granulação do solo. Contudo, esta variável é um bom indicador preliminar da concentração de oxigênio no microhbitat usado pela espécie durante a estivação.

\subsection{Medida de taxa metabólica}

A taxa metabólica em repouso dos indivíduos capturados em atividade (estação chuvosa) e enterrados (estação seca) foi estimada a partir de medidas de consumo de oxigênio através de um sistema de respirometria de fluxo 
intermitente com lavagem sequencial de câmaras metabólicas, sendo essas medidas realizadas a $30^{\circ} \mathrm{C}$. Foram utilizadas câmaras de acrílico de $400 \mathrm{~mL}$ preenchidas com areia esterilizada e ligadas a válvulas de controle de fluxo de ar. No início da coleta de dados, as câmaras foram lavadas com um fluxo constante de ar $(300 \mathrm{~mL} / \mathrm{min})$ durante 15 minutos, tempo suficiente para que todo o ar da câmara fosse renovado. Em seguida as câmaras foram fechadas durante 75 minutos e posteriormente abertas para uma nova lavagem com ar de 15 minutos de duração. A mistura de ar era primeiramente conduzida através de um filtro contendo sílica gel para a absorção do vapor de água e Ascarite para a absorção do gás carbônico e posteriormente para o analisador de oxigênio PA-1 (Sable Systems). O analisador de oxigênio esteve conectado a uma interface que enviava o sinal digitalizado para um computador, onde a aquisição, armazenamento e analise dos resultados foram executados pelo programa Datacan $\mathrm{V}$ (Sable Systems). O consumo de oxigênio foi calculado a partir da integral da curva de concentração de oxigênio contra o tempo registrado no computador, multiplicada pelo fluxo de ar utilizado durante a aquisição dos dados e dividida pelo tempo em que as câmaras permaneceram fechadas. Os valores obtidos foram convertidos para condições normais de temperatura e pressão (CNTP).

A taxa metabólica durante a locomoção forçada foi realizada através de respirometria fechada, com o auxilio de uma seringa de $50 \mathrm{~mL}$ acoplada a uma torneira para controlar a passagem de ar. $\mathrm{O}$ animal foi colocado dentro da seringa com um volume de $30 \mathrm{~mL}$ e estimulado ao exercício de deslocamento dentro da seringa durante 5 minutos com a câmara fechada, em uma temperatura média de $30^{\circ} \mathrm{C}$. Após esse intervalo uma amostra de ar de $20 \mathrm{~mL}$ 
foi injetada a um fluxo constante, através do sistema de filtro, e o consumo de oxigênio foi calculado como citado anteriormente.

\subsection{Desempenho locomotor}

Os animais foram estimulados a saltar em uma pista de 1,6m de comprimento por $18 \mathrm{~cm}$ de largura, o tempo requerido para percorrer $1 \mathrm{~m}$ foi medido através de um cronômetro digital JS 307 Junsd. Cada animal percorreu 3 vezes o percurso. Foi utilizada a média dos tempos de cada individuo. Os testes foram realizados a $29,3^{\circ} \mathrm{C} \pm 0,2$ (média \pm erro padrão).

\subsection{Anatomia Interna}

Os animais utilizados nas medidas de consumo de oxigênio tiveram alguns órgãos como o estômago e o intestino analisados, estes foram abertos e o eventual conteúdo foi removido e pesado. Os corpos gordurosos, quando presentes, foram retirados e pesados e a porcentagem em relação a massa total do animal foi expressa. Todos esses valores expressos em proporções foram transformados mediante uma função arco-seno previamente às análises estatísticas.

\subsection{Tratamento das amostras de tecido}

Outros animais foram capturados nas mesmas fases descritas anteriormente ("seca”, "chuvosa" e "possível emergência em um ano atípico, PEAA") e imediatamente sacrificados, através da imersão em nitrogênio líquido no próprio local de estudo. Após o congelamento, estes permaneceram armazenados em nitrogênio líquido e foram levados em gelo seco ao 
laboratório do Instituto de Biociências da USP em São Paulo para a estocagem em freezer $-85^{\circ} \mathrm{C}$ até o momento de uso. Os animais tiveram seus tecidos separados em almofariz contendo nitrogênio líquido para evitar o descongelamento. Foram separados para as medidas de atividade enzimática os músculos dos membros posteriores, o coração e o fígado. Nestas mesmas amostras de tecidos, foram feitas medidas do conteúdo de proteínas solúveis, lipídeos totais, glicose e glicogênio, baseados em métodos descritos em KEPPLER \& DECKER, (1984); KNIGHT et. al., (1972) e FOLCH et. al., (1957).

Para as medidas de atividade enzimática e determinação do conteúdo de proteínas solúveis, as amostras de tecido foram descongeladas e homogeneizadas em 9 volumes de tampão Imidazol-HCl-20mM (pH 7,4) contendo EDTA-2mM, NaF-20mM, PMSF-1mM e Triton X-100-0,1\%, mantidas sobre gelo, em um homogeneizador Ultra Turrax (IKA LaborTechnik). A ruptura das membranas mitocondriais foi efetuada por meio de sonicação, utilizando-se um sonicador U-200 Scontrol (IKA LaborTechnik).

\subsection{Atividade Enzimática}

Foram determinadas as atividades das enzimas: piruvato quinase (PK) e lactato desidrogenase (LDH), ambas pertencentes à via glicolítica, citrato sintase (CS), do Ciclo de Krebs; e $\beta$-hidroxiacil-CoA desidrogenase (HOAD) pertencente à via da $\beta$-oxidação lipídica. Para isso foi utilizado um espectrofotômetro Beckman DU-70 equipado com controlador de temperatura Peltier (Beckman), e cubetas de vidro pra $700 \mu \mathrm{L}$. Foram utilizados métodos de alteração na absorbância de NADH e NADP ${ }^{+}$a 340nm, ou DTNB a 412nm, em condições de saturação de substrato e não inibitórias, de acordo com as 
modificações feitas a partir de Begmeyer (1983) descritas a seguir. Os ensaios foram realizados a $25^{\circ} \mathrm{C}$ e o $\mathrm{pH}$ foi ajustado de acordo com as características funcionais de cada enzima.

PK (E.C. 2.7.1.40) - O meio de reação foi constituído de tampão Imidazol-HCl a $100 \mathrm{mM}$ de concentração final (pH 7,0); $\mathrm{MgCl}_{2}$ a $10 \mathrm{mM} ; \mathrm{KCl}$ a $100 \mathrm{mM} ; \mathrm{ADP}$ a 2,5mM; F1,6P 2 a $0,02 \mathrm{mM} ; \mathrm{NADH}$ a $0,15 \mathrm{mM}$; LDH a $12,1 \mathrm{U} \cdot \mathrm{mL}^{-1}$ e extrato homogeneizado diluído. Nesta etapa foi realizada uma primeira medida para o controle de eventuais alterações de absorbância (controle) por 3 minutos, quando foi adicionado o substrato fosfo(enol)piruvato a 2,5mM e a variação de absorbância novamente acompanhada por mais 3 minutos.

LDH (E.C. 1.1.1.27) - O meio de reação foi constituído de tampão Imidazol-HCl a 100mM de concentração final $(\mathrm{pH} 7,0)$; DTT a $5 \mathrm{mM}$; NADH a $0,15 \mathrm{mM}$ e extrato homogeneizado diluído. Nesta etapa foi realizada uma primeira medida para o controle de eventuais alterações de absorbância (controle) por 3 minutos, quando foi adicionado o substrato piruvato a $1 \mathrm{mM}$ e a variação de absorbância novamente acompanhada por mais 3 minutos.

CS (E.C. 4.1.3.7) - O meio de reação foi constituído de tampão Tris- $\mathrm{HCl}$ a 50mM de concentração final $(\mathrm{pH} 8,0)$; DTNB a $0,1 \mathrm{mM}$; acetil-CoA a 0,2mM, extrato homogeneizado diluído. Nesta etapa foi realizada uma primeira medida para o controle de eventuais alterações de absorbância (controle) por 3 minutos, quando foi adicionado o substrato oxaloacetato a $0,9 \mathrm{mM}$ e a variação de absorbância novamente acompanhada por mais 3 minutos. 
HOAD (E.C. 1.1.1.35) - O meio de reação foi constituído de tampão Imidazol$\mathrm{HCl}$ a $100 \mathrm{mM}$ de concentração final $(\mathrm{pH} 7,0) ; \mathrm{NADH}$ a $0,15 \mathrm{mM}$ e extrato homogeneizado diluído. Nesta etapa foi realizada uma primeira medida para o controle de eventuais alterações de absorbância (controle) por 3 minutos, quando foi adicionado o substrato acetoacetil-CoA a $0,1 \mathrm{mM}$ e a variação de absorbância novamente acompanhada por mais 3 minutos. Todos os ensaios foram realizados no mínimo em duplicata e a atividade enzimática foi calculada a partir da equação:

Atividade Enzimática $=\left[\left(\Delta\right.\right.$ Abs $\left.\cdot \mathrm{min}^{-1}\right) \cdot$ diluição total $] /(\varepsilon \cdot d)$

onde " $\Delta$ Abs.min ${ }^{-1}$ " é a variação de absorbância por minuto após a adição de substrato menos a variação de absorbância do controle; "diluição total" é a diluição total da amostra de tecido; " $\varepsilon$ " é o coeficiente de absorção molar para o NADH $\left(6,22 \cdot 10^{2}\right.$ L.mol $\left.{ }^{-1} \cdot \mathrm{mm}^{-1}\right)$ ou DTNB $\left(13,6 \cdot 10^{2}\right.$ L.mol $\left.{ }^{-1} \cdot \mathrm{mm}^{-1}\right)$; e "d" é a distância percorrida pelo feixe de luz na solução (igual a $10 \mathrm{~mm}$ em todos os ensaios).

Os resultados de atividade enzimática foram expressos em $\mu \mathrm{mol}$ de substrato convertido a produto por minuto por grama de tecido úmido, equivalente a unidade U.g tecido ${ }^{-1}(\mathrm{SI})$.

\subsection{Concentração de lipídios totais}

O teor de lipídeos totais foi determinado usando com pequenas modificações os métodos descritos por FRINGS \& DUNN (1970); FRINGS et. al. (1972) e KNIGHT et. al. (1972), sobre a reação com fosfovanilina medida a $540 \mathrm{~nm}$, As amostras de tecido foram previamente submetidas ao processo de 
extração conforme estabelecido por FOLCH et. al. (1957) e PARRISH, (1998), com o emprego de uma mistura de clorofórmio e metanol.

As amostras foram homogeneizadas em 50 volumes de uma solução clorofórmio:metanol $(2: 1 ; \mathrm{v} / \mathrm{v})$, e 7 volumes de água destilada, em um homogeneizador Ultra-Turrax (IKA LaborTechnik) por cerca de 3 minutos. O extrato foi centrifugado por 3 minutos a $8000 \mathrm{~g}$ quando foi formado um sistema de duas fases. A fase inferior foi totalmente recolhida por uma pipeta Paster, tomando-se cuidado para não misturar as duas fases. A fase recolhida foi colocada em outro frasco com tampa onde foi adicionado 5 volumes (em relação à solução de clorofórmio:metanol:cloreto de magnésio - 0,034\% (3:50:50; v/v). Em seguida foi adicionado ao liquido remanescente cerca de 1/3 de seu volume de metanol puro (ou quantidade suficiente para a formação de um sistema de fase única). $\mathrm{O}$ frasco foi colocado aberto em estufa a $60^{\circ} \mathrm{C}$ durante 24 horas para a evaporação completa dos solventes. Após esse tempo, foi adicionado $1 \mathrm{~mL}$ de clorofórmio puro ao frasco, que foi mantido fechado em freezer $-20^{\circ} \mathrm{C}$ até o momento dos ensaios para a determinação da concentração de lipídeos totais.

Para a determinação da concentração de lipídeos totais foi colocado $20 \mu \mathrm{L}$ da solução proveniente da extração em um tubo de ensaio. O tubo foi colocado em estufa a $60^{\circ} \mathrm{C}$ para evaporação total do solvente, posteriormente foi acrescido $200 \mu \mathrm{L}$ de ácido sulfúrico puro e a mistura foi fervida em banhomaria por 10 minutos. Após esse intervalo, foi adicionado $5 \mathrm{~mL}$ de fosfovanilina e a mistura foi incubada por 15 minutos a $37^{\circ} \mathrm{C}$. A absorbância da solução foi lida a 540nm, no máximo, 30 minutos após a incubação. O cálculo da concentração de lipídeos totais foi realizada através da equação linear de uma 
curva-padrão construída utilizando-se a massa de lipídeos totais contidas em uma solução padrão de óleo de fígado de bacalhau (Sigma, C5650), submetida aos mesmos procedimentos de dosagem. Os resultados foram expressos em miligrama de lipídeo por grama de tecido úmido.

\subsection{Concentração de proteínas}

A concentração de proteínas solúveis foi determinada com base no método descrito por LoWRY et. al. (1951) segundo a reação de Folin Ciocalteau. Os ensaios foram preparados com o extrato bruto diluído 1:10 em água milliQ, misturado com uma solução contendo tartarato de sódio a $4 \%$, $\mathrm{CuSO}_{4}$ a $2 \%$ e $\mathrm{NaCO}_{3}$ anidro $+\mathrm{NaOH}$. Decorridos 10 minutos foi acrescentado o reativo de Folin e após 30 minutos foi feita a leitura da absorbância no espectrofotômetro a 660nm no espectrofotômetro de placa SpectraMax 250 (Molecular Device). A concentração de proteínas nas amostras de tecido foi calculada a partir da equação da reta obtida com o padrão de solução de albumina bovina de grande pureza e os valores foram expressos em miligramas de proteína solúvel por grama de tecido úmido.

\subsection{Concentração de glicogênio e glicose}

As amostras de tecido foram fragmentadas em almofariz com nitrogênio líquido. Foram adicionados 4 volumes de ácido perclórico (PCA) a 0,6M, acrescido de $1 \mathrm{mM}$ de EDTA, ao tecido ainda congelado para proceder a desproteinização da amostra. A mistura foi então triturada em um homogeinizador Ultra-Turrax (IKA LaborTechnik) e centrifugada a 8000g por 10 
minutos. O sobrenadante foi recolhido e mantido a $0^{\circ} \mathrm{C}$ até o momento do ensaio.

Para a medida da concentração de glicogênio foram realizadas duas etapas distintas, segundo KEPPLER \& DECKER (1984). Na primeira, uma fração do extrato ácido, obtido com a homogeneização do tecido em PCA-0,6M, foi utilizada para a medida da concentração de D-glicose para se obter a "concentração residual de glicose" na amostra. Estes valores foram utilizados como uma medida da concentração de glicose nas amostras de tecido. $\mathrm{Na}$ segunda etapa uma outra fração deste extrato ácido foi incubada em um ensaio com a enzima amiloglicosidase (E.C. 3.2.1.3) para a hidrólise das unidades glicosil que formam o polímero glicogênio. Ao final do tempo de incubação, quando as unidades glicosil foram totalmente liberadas, foi feita uma medida da concentração de D-glicose neste segundo extrato. A diferença entre a concentração de glicose entre o extrato incubado e 0 não incubado (concentração residual de glicose) foi utilizada no cálculo da concentração de glicogênio na amostra de tecido.

Para a hidrólise do glicogênio foram utilizados $20 \mu \mathrm{L}$ de extrato ácido incubados a $40^{\circ} \mathrm{C}$ com $10 \mu \mathrm{L}$ de $\mathrm{KHCO}_{3}-1 \mathrm{M}$ e $200 \mu \mathrm{L}$ de $\mathrm{AG}-10 \mathrm{UmL}^{-1} \mathrm{em}$ tampão acetato-ácido acético $0,2 \mathrm{M}(\mathrm{pH} 4,8)$ por 4 horas. Após este tempo, a reação foi interrompida com $50 \mu \mathrm{L}$ de PCA - 70\%.

Os dois extratos (incubado e não incubado) foram neutralizados com $\mathrm{K}_{2} \mathrm{CO}_{3}-3 \mathrm{M}$, centrifugados por 1 minuto a $8000 \mathrm{~g}$ e utilizados nos ensaios para a medida da concentração de D-glicose.

Para a medida da concentração de D-glicose foi utilizado um método baseado nas alterações de absorbância do $\mathrm{NAD}^{+}$, a $340 \mathrm{~nm}$, em um 
espectrofotômetro de placa SpectraMax 250 (molecular Device) a $25^{\circ} \mathrm{C}$. O protocolo foi modificado a partir de Keppler e Decker (1984) como descrito a seguir:

D-glicose - O meio de reação foi constituído de tampão $\mathrm{NaH}_{2} \mathrm{PO}_{4}$ a $100 \mathrm{nM}$ $(\mathrm{pH} 7,7) ; \mathrm{MgSO}_{4}$ a 3,8mM; ATP a $1,5 \mathrm{mM}$; $\mathrm{NAD}^{+}$a $1,5 \mathrm{mM}$ e amostra neutralizada. Nesta etapa, a alteração de absorbância foi monitorada até o valor constante (A1). Em seguida adicionou-se hexoquinase a $2 \mathrm{U} \cdot \mathrm{mL}^{-1} \mathrm{e}$ glicose-6-fosfato desidrogenase a $2 \mathrm{U} \cdot \mathrm{mL}^{-1}$ e novamente monitorou-se a absorbância até um valor constante (A2).

Os ensaios foram realizados no mínimo em duplicata e os resultados expressos em miligramas de glicose por grama de tecido úmido $(\mathrm{mg} / \mathrm{g})$. O volume final de cada ensaio foi de $350 \mu \mathrm{L}$, o que resulta em uma distância de $0,65 \mathrm{~cm}$ para a passagem do feixe de luz através da solução no espectrofotômetro usado. As concentrações de glicose nos tecidos foram então calculadas a partir da equação:

mg.g tecido úmido ${ }^{-1}=(\Delta$ Abs . diluição total da amostra.$P M) /(\varepsilon . d .1000)$ onde " $\triangle \mathrm{Abs}$ " é a variação de absorbância dada por A2-A1 descontadas as alterações resultantes de um ensaio em branco preparado com tampão ao invés de amostra). "PM" é o peso molecular da D-glicose $(=180,16)$; " $\varepsilon$ " é o coeficiente de absorção molar do $\operatorname{NAD}^{+}\left(=6,22 \mathrm{~mL} \cdot \mathrm{mol}^{-1} \cdot \mathrm{mm}^{-1}\right)$ e "d" é a distancia percorrida pelo feixe de luz na solução. A diluição total da amostra compreende as diluições envolvidas no processo de desproteinizacão, neutralização, incubação e preparação do ensaio.

A concentração de glicogênio foi calculada a partir da diferença entre a concentração de D-glicose nos extratos que foram incubados com 
amiloglicosidase em relação aqueles que não foram incubados (concentração residual de glicose na amostra). Os resultados foram expressos em $\mathrm{mg}$ de glicogênio por grama de tecido úmido.

Para testar a eficiência dos ensaios para a determinação das concentrações de D-glicose e glicogênio, foram preparadas curvas-padrão empregando-se substancias químicas comercialmente disponíveis e de alto grau de pureza (Sigma-Aldrich Co.), possibilitando assim a validação dos protocolos empregados dentro de uma faixa de concentração do metabólito no ensaio.

\subsection{Análise dos Dados}

Os valores obtidos referentes à concentração de metabólitos e a atividade enzimática nas duas fases marcantes estudadas, mais a fase atípica, foram analisados através de uma ANOVA para amostras independentes no nível de significância de 0,05 . Nos casos em que os dados não seguiram as exigências de homogeneidade de variâncias e normalidade, foi utilizado o teste não paramétrico Kruskal-Waliis para análise dos grupos. Para a comparação a posteriori entre grupos foi utilizado o teste Tukey. Todas as análises estatísticas foram aplicadas segundo ZAR (1996), com o auxílio dos programas Minitab 12 (Minitab Inc.) e SPSS (SPSS Software). 


\section{RESULTADOS}

\subsection{Caracterização do microhábitat de estivação de $P$. diplolistris na área}

de estudo

Os dados médios de umidade relativa e temperatura típicos de microhabtats para estivação a 80 e $40 \mathrm{~cm}$ aparecem na Tabela 01, enquanto que a Figura 03 ilustra o curso da variação ao longo do tempo. A perda de água em 72 horas medida através do uso de modelos de agar, é maior em profundidades menores e diminui consideravelmente a partir de $40 \mathrm{~cm}$ de profundidade (Figura 04). A perda de água é menor que $10 \%$ do peso inicial a partir de 80 centímetros de profundidade. Os modelos de agar enterrados a $40 \mathrm{~cm}$ ou mais mostram uma perda de água significativamente menor que os enterrados a profundidades inferiores a esse valor. A concentração de oxigênio no solo é mostrada na Figura 05, onde é possível ver em detalhe a mudança significativa que ocorre na concentração de oxigênio em profundidades igual ou maiores que $75 \mathrm{~cm}$.

Tabela 01. Média e erro padrão das medidas de umidade relativa (\%) e temperatura $\left({ }^{\circ} \mathrm{C}\right)$ no abrigo de Pleurodema diplolistris durante a estiagem. Medidas realizadas durante 90 dias.

\begin{tabular}{ccccc}
\hline & \multicolumn{4}{c}{ Profundidade (cm) } \\
\cline { 2 - 5 } & \multicolumn{3}{c}{$\mathbf{8 0}$} & \multicolumn{2}{c}{40} \\
\hline & $\begin{array}{c}\text { Umidade } \\
\text { Relativa (\%) }\end{array}$ & $\begin{array}{c}\text { Temperatura } \\
\left({ }^{\circ} \mathrm{C}\right)\end{array}$ & $\begin{array}{c}\text { Umidade } \\
\text { Relativa (\%) }\end{array}$ & $\begin{array}{c}\text { Temperatura } \\
\left({ }^{\circ} \mathrm{C}\right)\end{array}$ \\
$\begin{array}{c}\text { Média } \pm \text { erro } \\
\text { padrão }\end{array}$ & $92,2 \pm 0,59$ & $32,9 \pm 0,05$ & $65,3 \pm 2,05$ & $32,6 \pm 0,05$ \\
\hline
\end{tabular}




\subsection{Teste de migração vertical}

Durante as coletas foram feitas medições das profundidades (Figura 06) em que os animais foram encontrados. Com o aumento do tempo de estiagem, ocorreu uma tendência, ainda que não significativa, da profundidade na qual os animais foram encontrados enterrados.

\subsection{Desempenho locomotor}

Os animais encontrados enterrados mostraram capacidade para locomoção mesmo após uma longa fase de estiagem (cerca de 6 meses). Contudo, a velocidade dos animais coletados durante a seca em testes de corrida $(0,16 \pm 0,01 \mathrm{~m} / \mathrm{s}$; média \pm erro padrão) foi $50 \%$ daqueles animais coletados durante a fase de chuva $(0,38 \pm 0,01 \mathrm{~m} / \mathrm{s}$; média \pm erro padrão), quando são encontrados naturalmente em atividade.

\subsection{Taxa metabólica de repouso e durante o exercício}

As taxas de consumo de $\mathrm{O}_{2}$ durante a atividade forçada nas duas estações observadas não foram significativamente diferentes. Entretanto, o consumo de $\mathrm{O}_{2}$ durante o repouso foi $50 \%$ menor durante a estação seca (Figura 07). O escopo metabólico fatorial durante a seca foi $41,3 \%$ menor do que o observado durante a estação chuvosa.

\subsection{Concentração de substratos energéticos}

Quando os animais saíram para a atividade no início da estação chuvosa a concentração de lipídeos nos músculos dos membros posteriores foi $50 \%$ menor que os valores observados em animais coletados durante a seca 
(Anova $F=18,3 ; p<0,05$ e Tukey $p<0,05 ;$ Figura 08). Já no fígado a concentração de lipídeos totais foi significativamente diferente nas três estações observadas (Anova $F=15,6 ; p<0,05$ e Tukey $p<0,05$ ), sendo esta maior durante a estação chamada PEAA (possível emergência em um ano atípico) e menor durante a estação chuvosa. Além disso, foi observada uma diminuição significativa na proporção de corpos gordurosos durante o início da fase chuvosa em relação à estiagem (cerca de 50,7\%; Teste t; $p<0,05$; Figura 09). Não foi encontrado alimento no estomago ou no intestino dos animais coletados durante a estação seca.

A concentração de glicogênio nos músculos dos membros posteriores foi $28,7 \%$ menor nos animais coletados durante a fase chuvosa em relação àqueles coletados na fase de seca (Anova $F=4,1, p<0,05$ e Tukey $p<0,05$; Figura 10). A concentração de glicose foi $58,4 \%$ maior durante a estação chuvosa (Anova $F=19,1, p<0,05$ e Tukey $p<0,05$ ). A concentração de proteínas solúveis nos músculos dos membros posteriores foi $7,1 \%$ menor nos animais coletados durante a estação chuvosa em relação aos animais coletados durante a estiagem (Anova $F=4,3 p<0,05$ e Tukey $p<0,05$; Figura 11), enquanto esta foi cerca de $21,2 \%$ maior no fígado durante a fase de atividade (Anova $F=27,4 p<0,05$ e Tukey $p<0,05)$ e $34,7 \%$ maior no coração neste mesma fase (Anova $F=23,7 p<0,05$ e Tukey $p<0,05$ ).

\subsection{Atividade enzimática}

A atividade máxima das enzimas citrato sintase (CS) e $\beta$-hidroxiacil-CoA desidrogenase (HOAD) foram 50,7 e 55,6\% menores respectivamente durante a estação seca no músculo dos membros posteriores em relação aos animais 
da estação chuvosa (Figura 12. CS: Anova F=9,3 $p<0,05$ e Tukey $p<0,05$; HOAD: Anova $F=17,4 p<0,05$ e Tukey $p<0,05)$. As atividades da CS e da HOAD no fígado também foram cerca de 54,3 e $44,3 \%$, respectivamente, menores durante a estiagem (CS: Anova F=11,6 $p<0,05$ e Tukey $p<0,05$, HOAD: Anova $F=17,9 p<0,05$ e Tukey $p<0,05)$. No coração também foi observado um valor cerca de $52,8 \%$ menor da atividade da CS e $71,3 \%$ menor da HOAD durante a estação seca em comparação com a estação chuvosa (CS: Anova F=8,8 $p<0,05$ e Tukey $p<0,05$, HOAD: Anova $F=40,4 p<0,05$ e Tukey $p<0,05)$.

A atividade máxima da lactato desidrogenase (LDH) não apresentou alteração significativa entre as duas estações marcantes e na estação atípica tanto nos músculos dos membros posteriores (Kruskal-Wallis, $\mathrm{P}=0,79$ ) quanto no fígado (Anova $F=0,88 p>0,05$ ). Durante o início da fase chuvosa, a atividade da LDH no coração foi $40,2 \%$ maior em comparação com a fase de seca (Anova $F=16,4 p<0,001$ e Tukey $p<0,05$ ). A atividade da piruvato quinase (PK) nos músculos dos membros posteriores se manteve sem alterações significativas em todas as estações analisadas (Anova $F=0,27$ e $p>0,05$; Figura 13). Contudo no fígado esta foi cerca de $22,4 \%$ maior durante a estiagem (Anova $\mathrm{F}=3,3 \mathrm{p}<0,05$ e Tukey $\mathrm{p}<0,04$ ) e $46,4 \%$ maior no coração durante a fase chuvosa (Anova $F=16,4 p<0,05$ e Tukey $p<0,05$ ).

\subsection{História natural e observações de campo}

Ao longo das atividades de campo foram feitas inúmeras observações que contribuem ao conhecimento da história natural de $P$. diplolistris, e que são consideradas, portanto parte desse trabalho. Um aspecto marcante do 
comportamento de se enterrar de $P$. diplolistris, refere-se à construção de uma câmara subterrânea no abrigo onde o animal permanece (Figura 2a). Aspecto que foi inicialmente relatado pelo pesquisador Carlos Jared (Instituto Butantan). Nesta, apenas a parte ventral do animal fica em contato direto com o solo. Evidências morfológicas sugerem ainda que a absorção de água pela região pélvica é mais rápida e essa posição adotada pelo animal auxilia na captação de água do solo (Carlos Jared, informação pessoal, mas veja também algo relacionado em Toledo \& JARED, 1993; JøRGENSEN, 1997). Diferentemente, sapos Scaphiopus hammondii são encontrados tanto na posição vertical quanto horizontal, em contato direto com o solo e sem a formação de uma câmara ao redor do corpo (RUIBAL, 1969).

As características do solo no microhábitat de $P$. diplolistris sugerem ser este um ambiente bastante propício para a permanência durante a fase de estiagem. O solo é relativamente bem oxigenado (ver sessão 5.1 , resultado do estudo de concentração de oxigênio) e apresenta uma temperatura parecida com a observada à noite quando os animais foram encontrados em atividade. Estes animais possuem ainda a pele aparentemente fina e semitransparente na região ingnal, característica esta que parece associada à captação de água, como observado em espécies dos gêneros Proceratophrys e Physalaemus (NAvAs et al., 2004). Animais desses grupos também são encontrados enterrados nas mesmas localidades onde são vistos $P$. diplolistris e a pele da região ventral desses animais exibe duas vezes mais vasos capilares em relação a espécies de ambientes não áridos (NAVAS et al., 2004; TOLEDO \& JARED, 1993). 
A síntese de proteínas em outros tecidos pode ser amplamente ativada no término da estivação dos anfíbios para a manutenção da produção dos gametas (Duellman \& Trueb, 1986). Foi visto em S. couchii que a gametogênese continua em ambos os sexos mesmo após a estação reprodutiva terminar (HARVEY et al, 1997; SHALAN et al, 2004), e que os ovos produzidos pelas fêmeas são reabsorvidos durante a estiagem quando a precipitação de chuva não é suficiente para a reprodução (SEYMOUR, 1973a). As fêmeas de $P$. diplolistris foram encontradas durante todo o ano, com ovários relativamente bem desenvolvidos e aparentemente aptas para a reprodução. Assim que as chuvas iniciam os indivíduos de $P$. diplolistris são encontrados em grande quantidade em poças de água, vocalizando e em amplexo. A manutenção da produção de gametas pode ter um significado importante para estes animais que exibem um comportamento de reprodução oportunista, quando as condições do ambiente tornam-se favoráveis com a imprevisível chegada da estação chuvosa. 


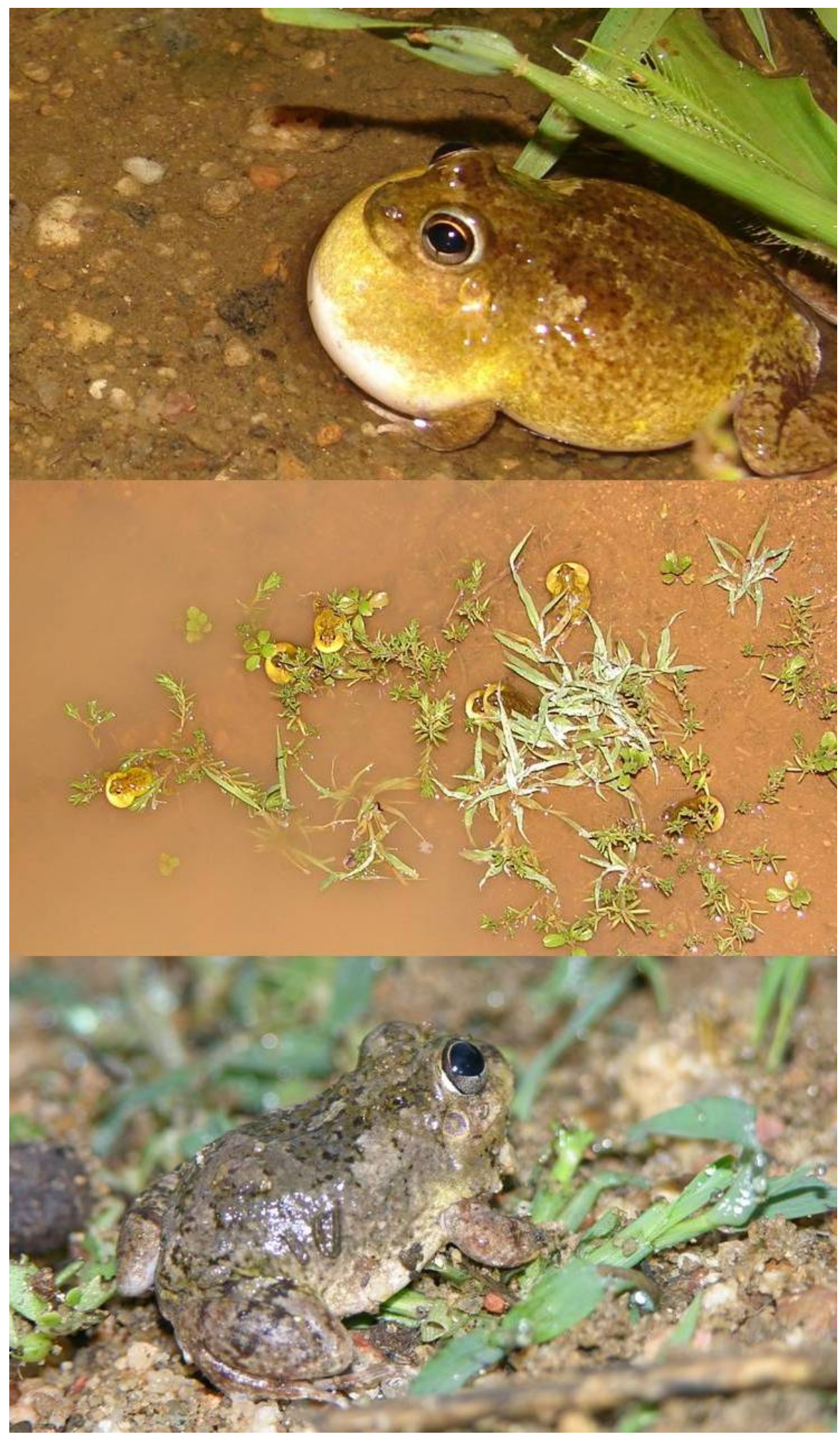

Figura 1. (a) Indivíduos machos de Pleurodema diplolistris coaxando durante a estação chuvosa em março de 2009. (b) Indivíduos de Pleurodema diplolistris em uma poça formada em uma estrada de terra, na primeira chuva da estação, em março de 2009 e (c) indivíduos de Pleurodema diplolistris forrageando, após 3 semanas de chuvas em março de 2009. 

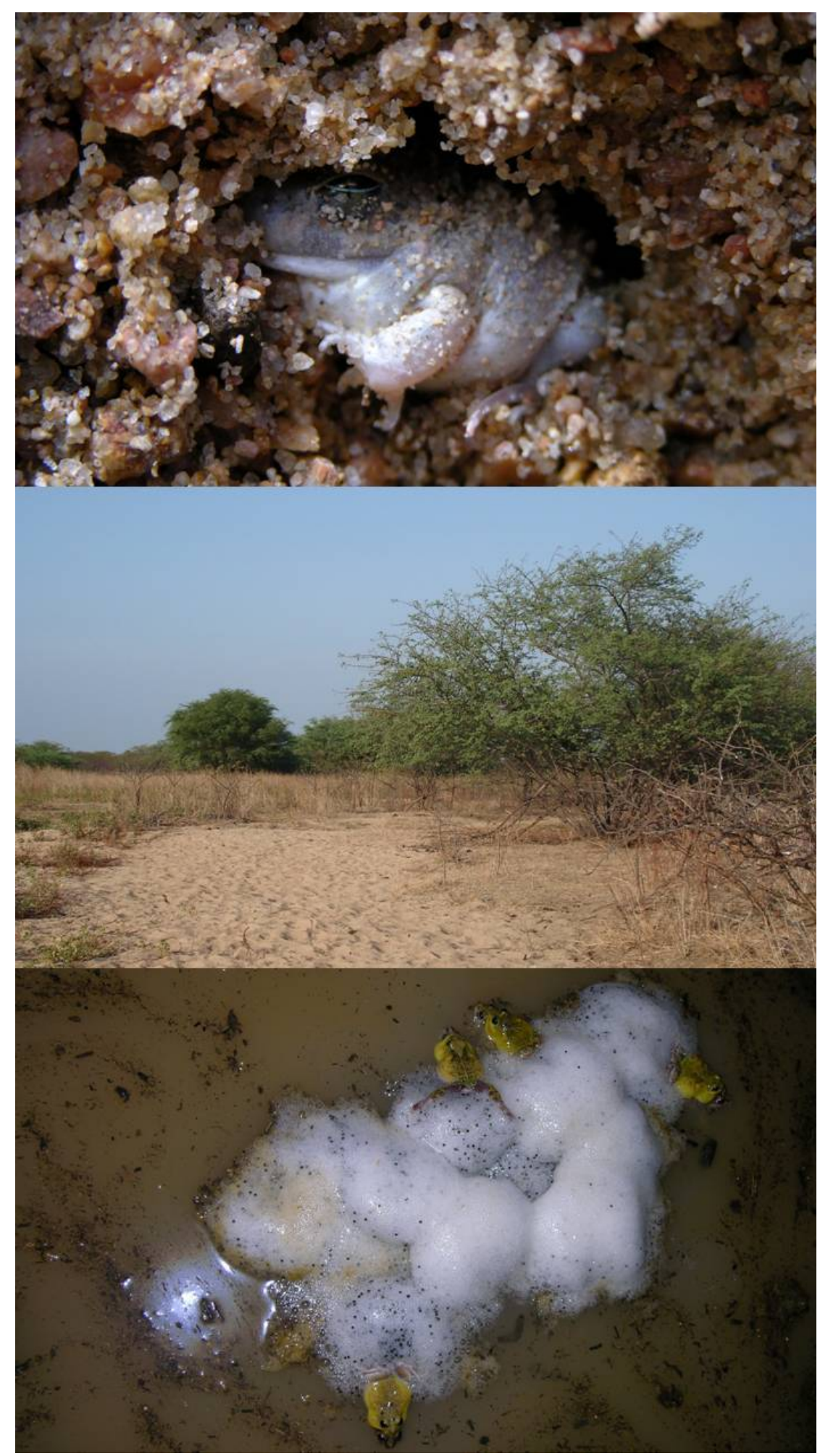

Figura 2. (a) Sapos Pleurodema diplolistris enterrados no leito do rio, 6 meses após a última chuva, em setembro de 2006. (b) Leito do Rio Sobradinho, onde Pleurodema diplolistris e outras espécies de anuros são encontradas enterradas durante os meses de estiagem. (c) Pleurodema diplolistris durante a primeira chuva da estação reprodutiva (Março de 2009). 


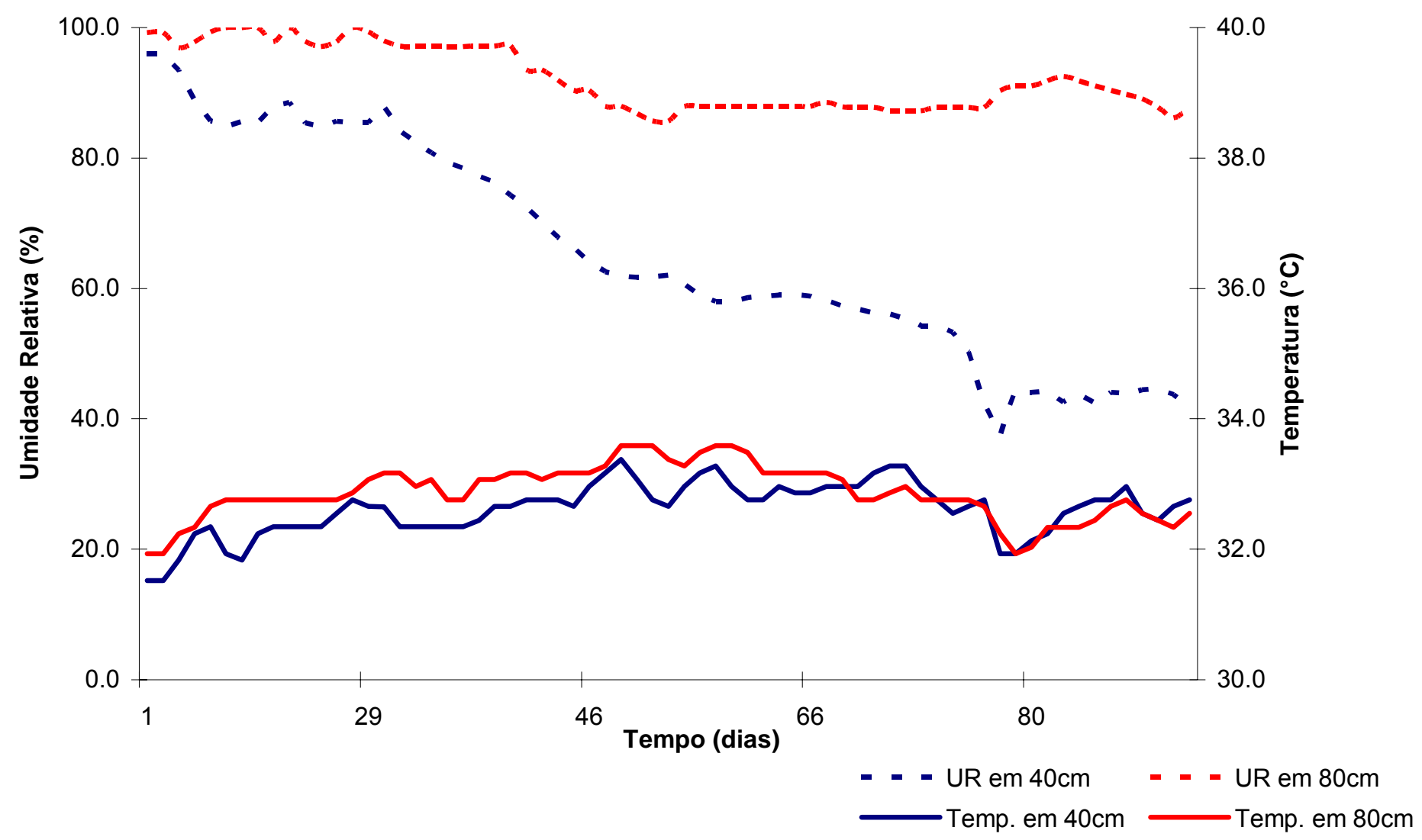

Figura 03. Umidade relativa $(\%)$ e temperatura $\left({ }^{\circ} \mathrm{C}\right)$ medidas a 40 e $80 \mathrm{~cm}$ de profundidade no solo do local onde foram coletados indivíduos de $P$. diplolistris, durante 90 dias (com início em 08 de setembro) na estiagem de 2006. 


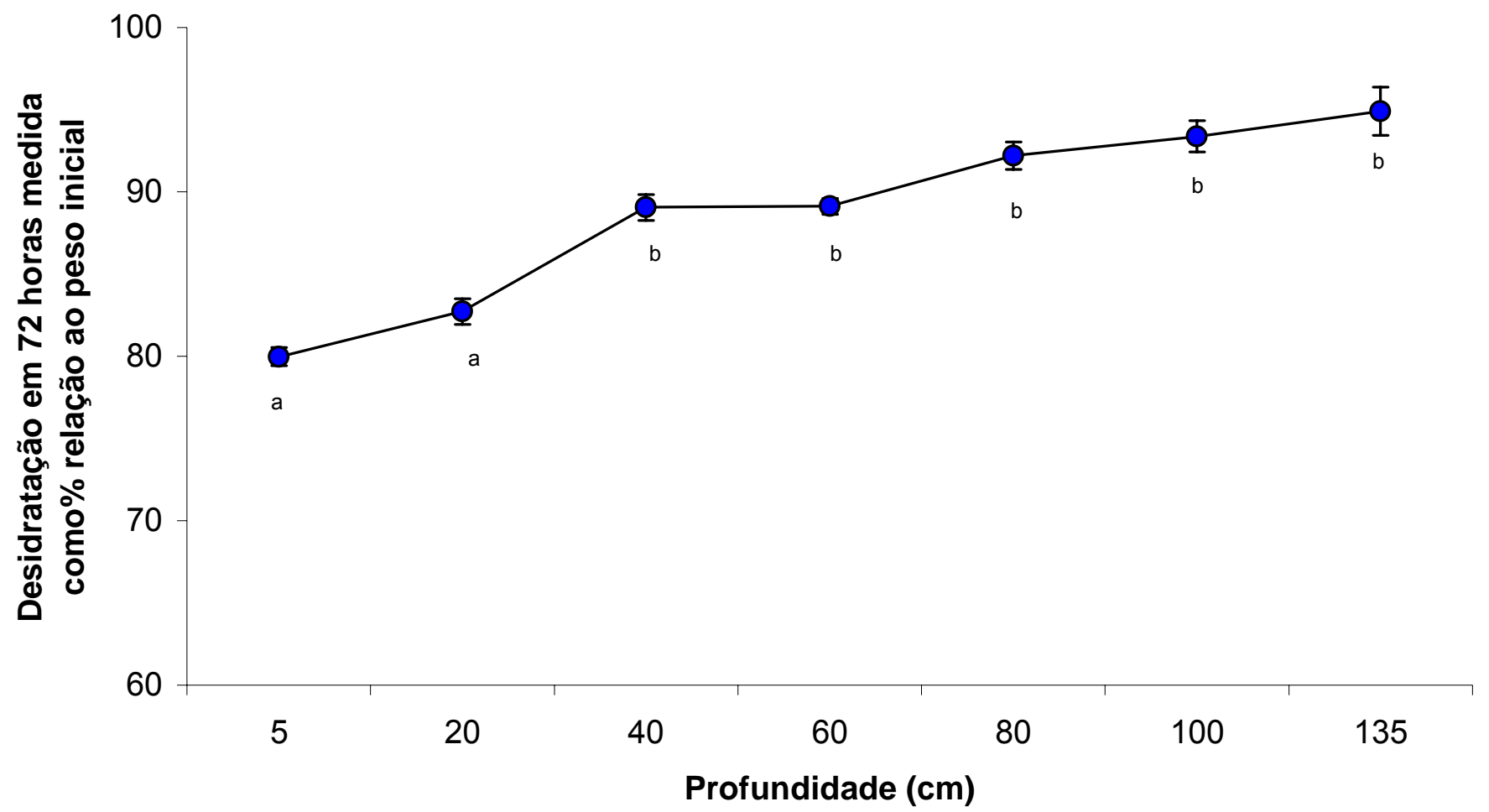

Figura 04. Massa dos modelos de agar enterrados a 5, 20,40,60,80, 100 e $135 \mathrm{~cm}$ no local onde foram coletados indivíduos de $P$. diplolistris. Os valores são expressos em porcentagem do peso final em relação ao peso inicial e representam a média e o erro padrão $(F=26,13$ e $p<0,05$, Tukey $p>0,05$, letras diferentes representam valores significativamente diferentes). Com 10 modelos enterrados em cada profundidade, durante 72 horas, pesando inicialmente $3,5 \pm 0,11$ gramas, média \pm erro padrão). 


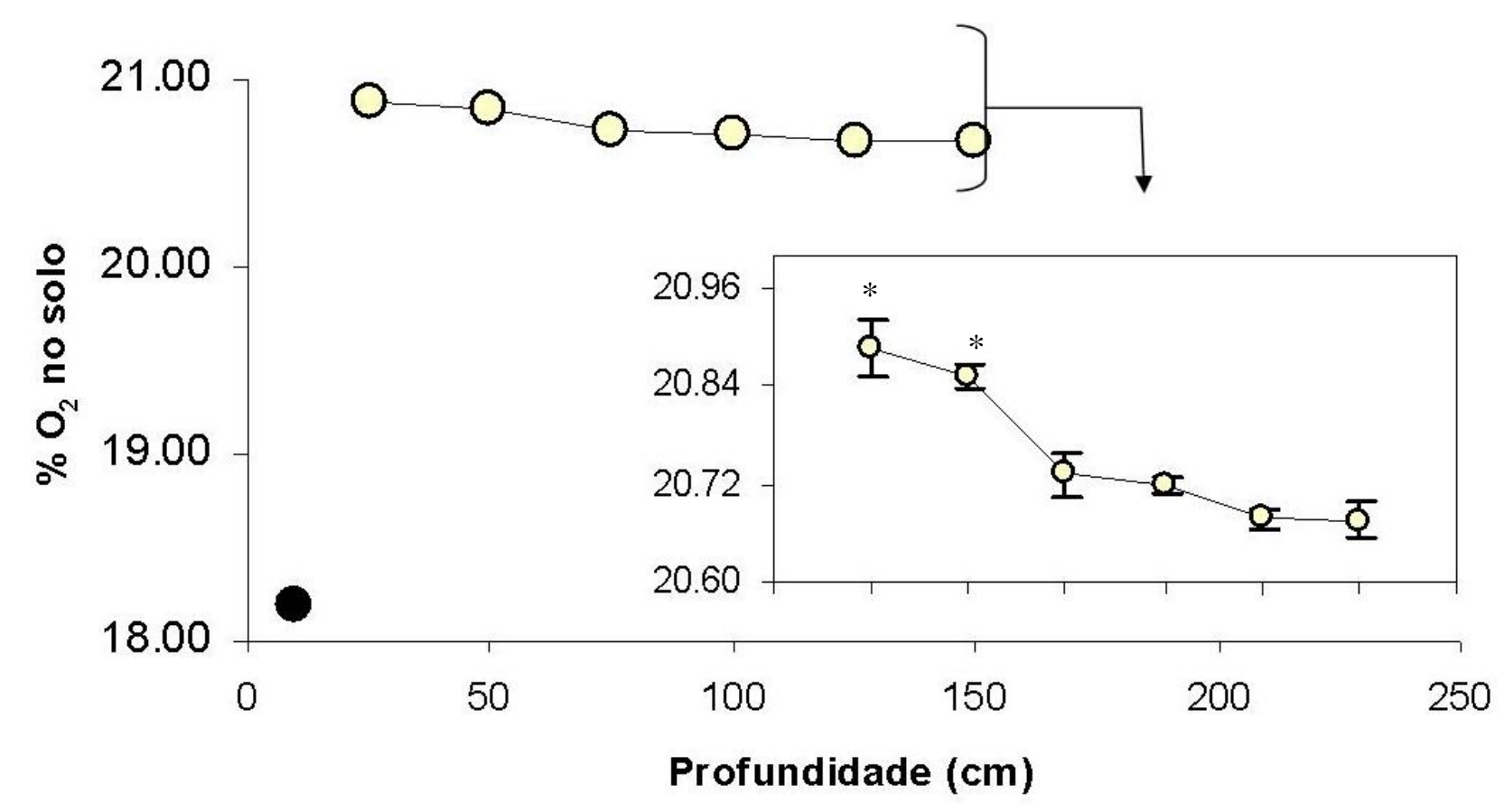

- P. diplolistris $\quad-$ S. couchii

Figura 05. Porcentagem de oxigênio (\%) no solo nas profundidades de 25,50,75, 100, 125 e 150cm no local onde foram coletados indivíduos de $P$. diplolistris. O circulo preenchido representa a concentração de $\mathrm{O}_{2}$ a $10 \mathrm{~cm}$ de profundidade para Scaphiopus couchii estivando (SEYMOUR, 1973c). A figura pequena ilustra em menor escala os dados obtidos com medida de dispersão (desvio padrão). Asteriscos representam valores significativamente diferentes. 


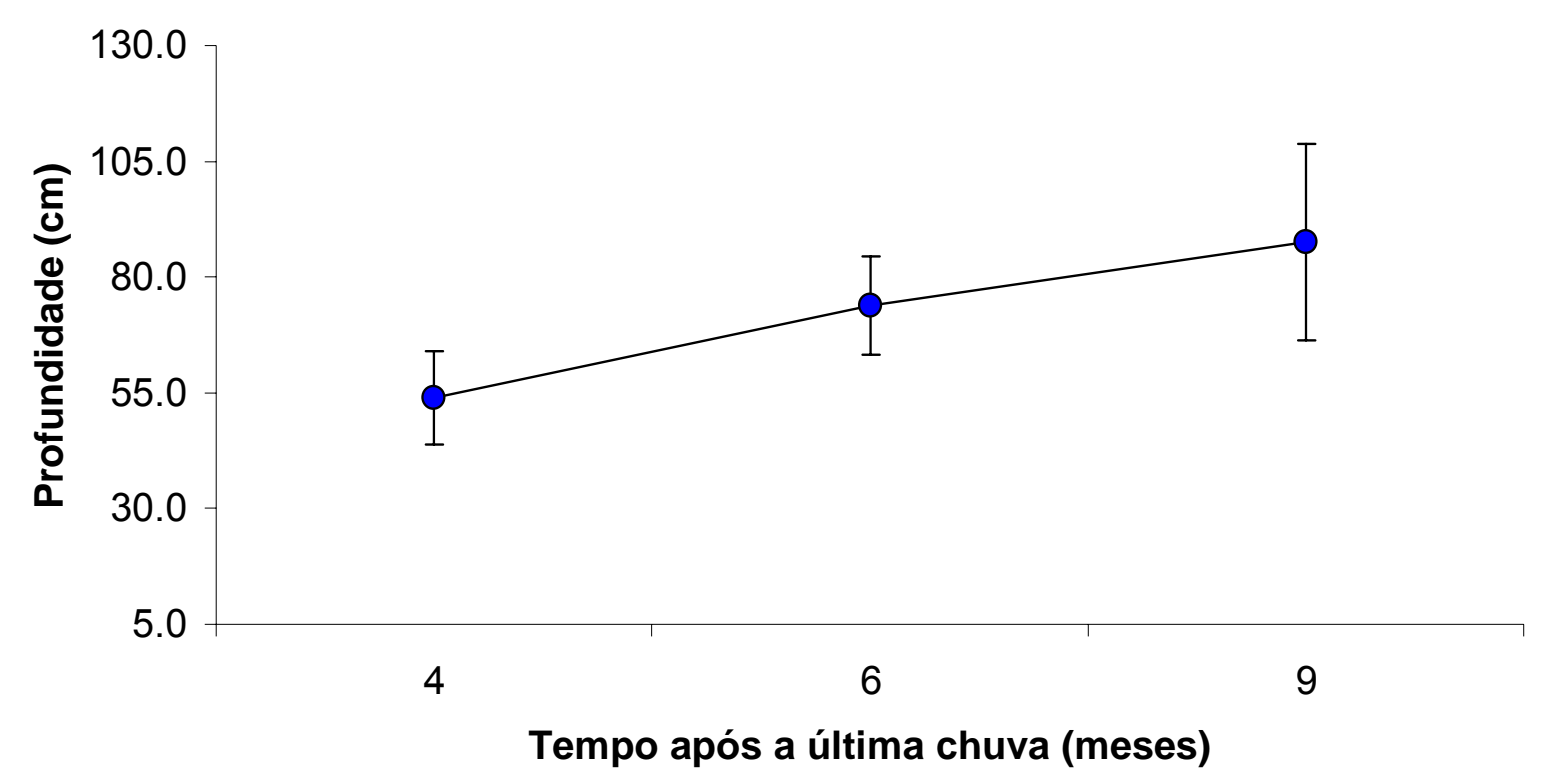

Figura 06. Profundidade $(\mathrm{cm})$ em que os indivíduos de $P$. diplolistris foram encontrados depois de 4,6 e 9 meses após a última chuva. Os valores representam a média e o erro padrão (Kruskal-Wallis $X^{2}=0,875, p>0,05$ ). 


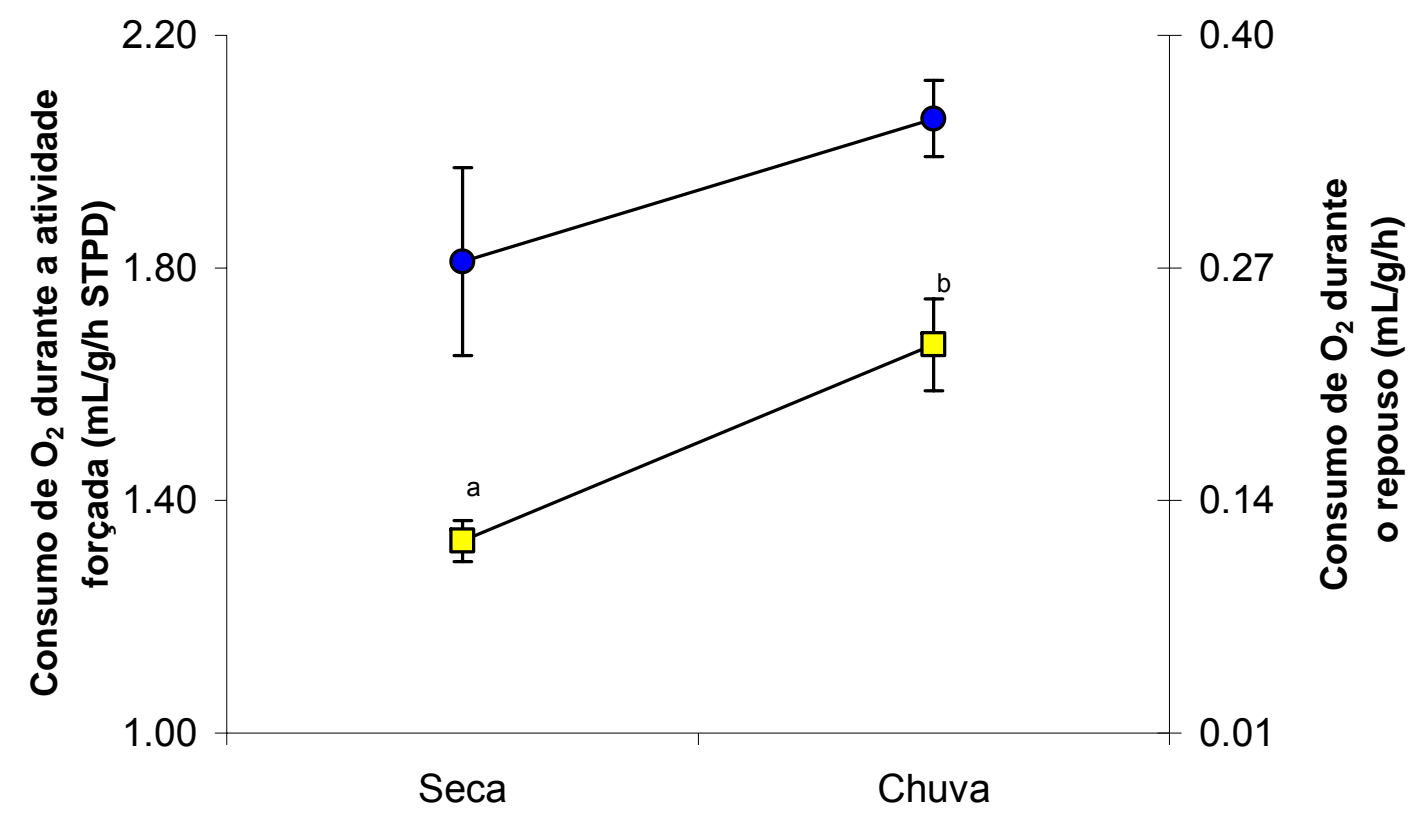

- Atividade $-\square-$ Repouso

Figura 07. Consumo de oxigênio $(\mathrm{mL} / \mathrm{g} / \mathrm{h}$ STPD) durante a atividade forçada e durante o repouso de indivíduos de $P$. diplolistris coletados nas estações seca e chuvosa. São representados valores da média e erro padrão para 10 animais em cada grupo. Letras diferentes representam valores significativamente diferentes (atividade test $t, t=1,4, p>0,05$; repouso, test $t, t=6,4, p<0,05$ ). 


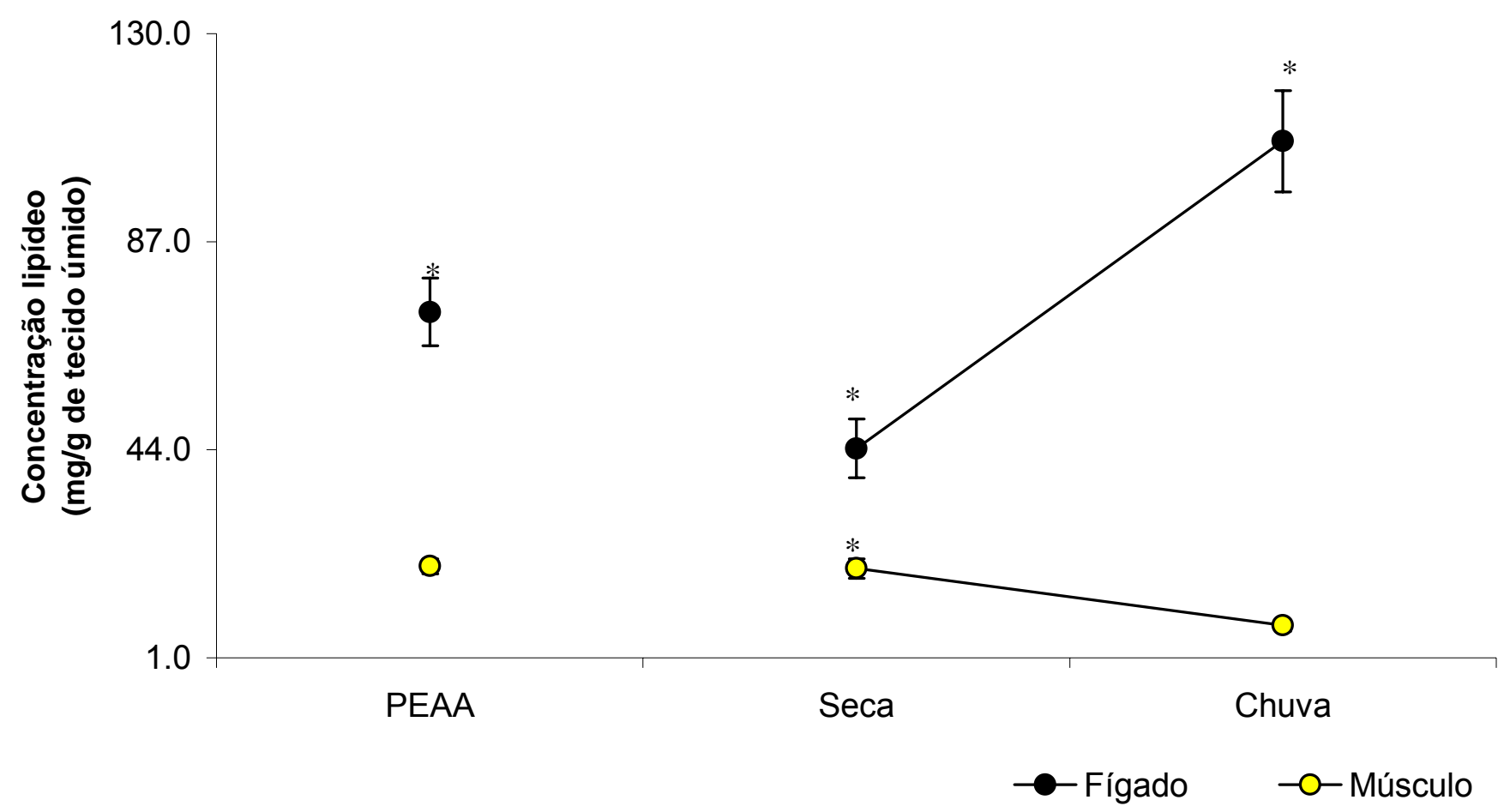

Figura 08. Concentração de lipídeo total nos músculos dos membros posteriores e fígado de indivíduos de $P$. diplolistris coletados em diferentes estações. Asteriscos representam valores significativamente diferentes. PEAA (Possível emergência em um ano atípico). 


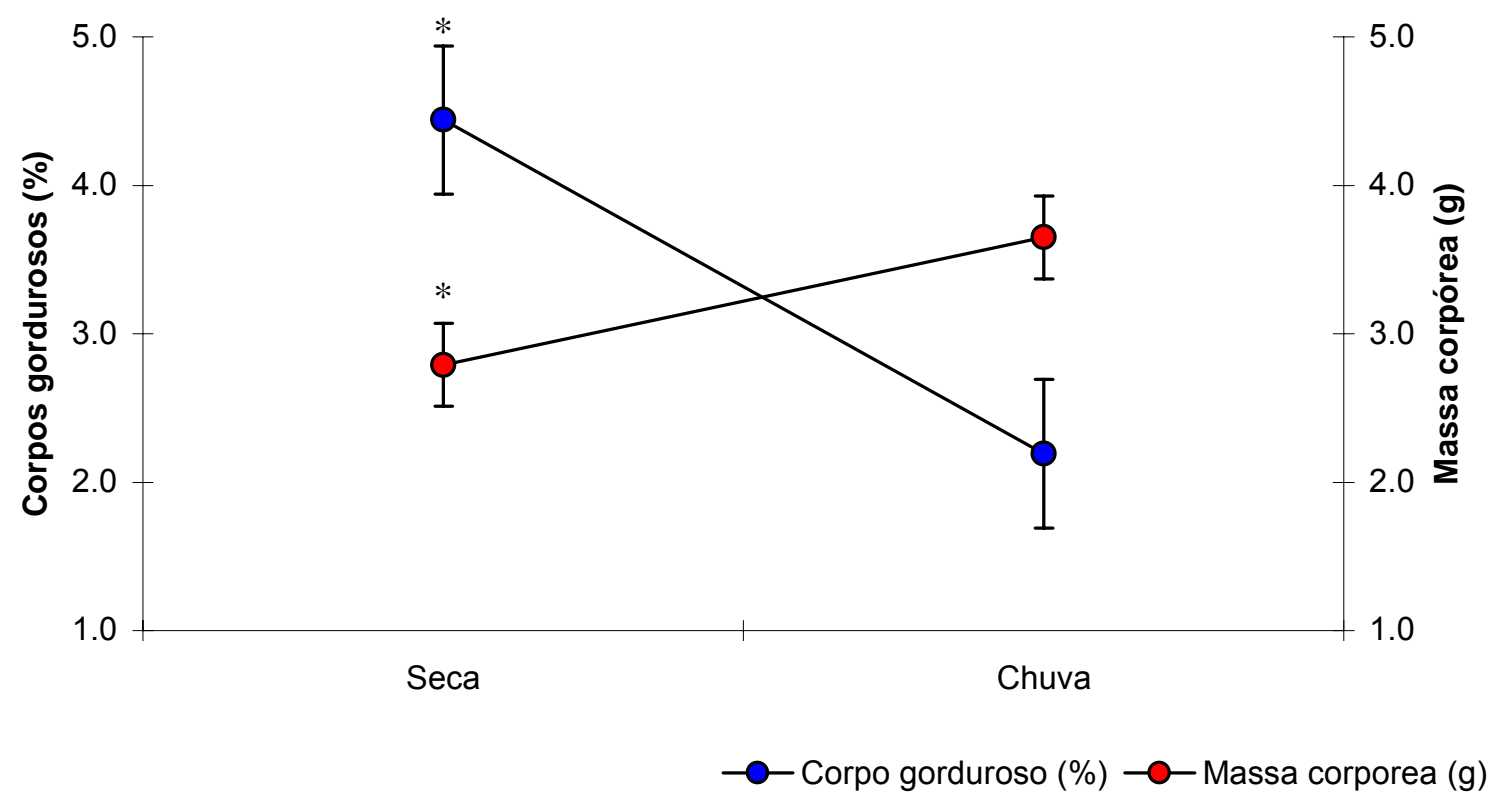

Figura 09. Massa dos indivíduos de $P$. diplolistris e porcentagem de corpos gordurosos em relação a massa total (grama) nas estações seca e chuvosa. Os valores significativamente diferentes são representados por asteriscos. 


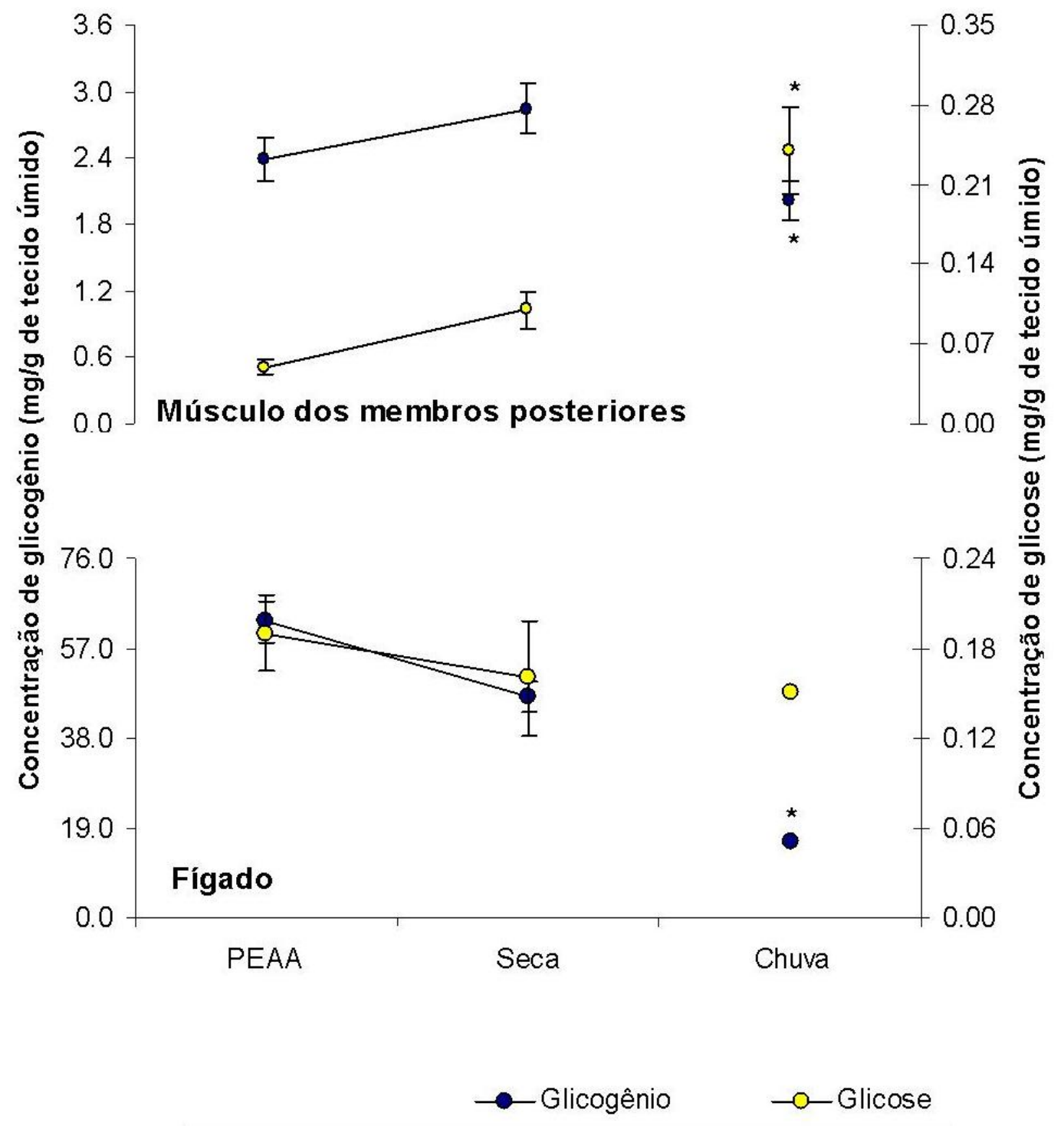

Figura 10. Concentração de glicogênio e glicose (ambos em $\mathrm{mg} / \mathrm{g}$ de tecido úmido) nos músculos dos membros posteriores e no fígado de indivíduos de $P$. diplolistris em diferentes fases do ano. Asteriscos representam valores significativamente diferentes. PEAA (Possível emergência ano atípico). 


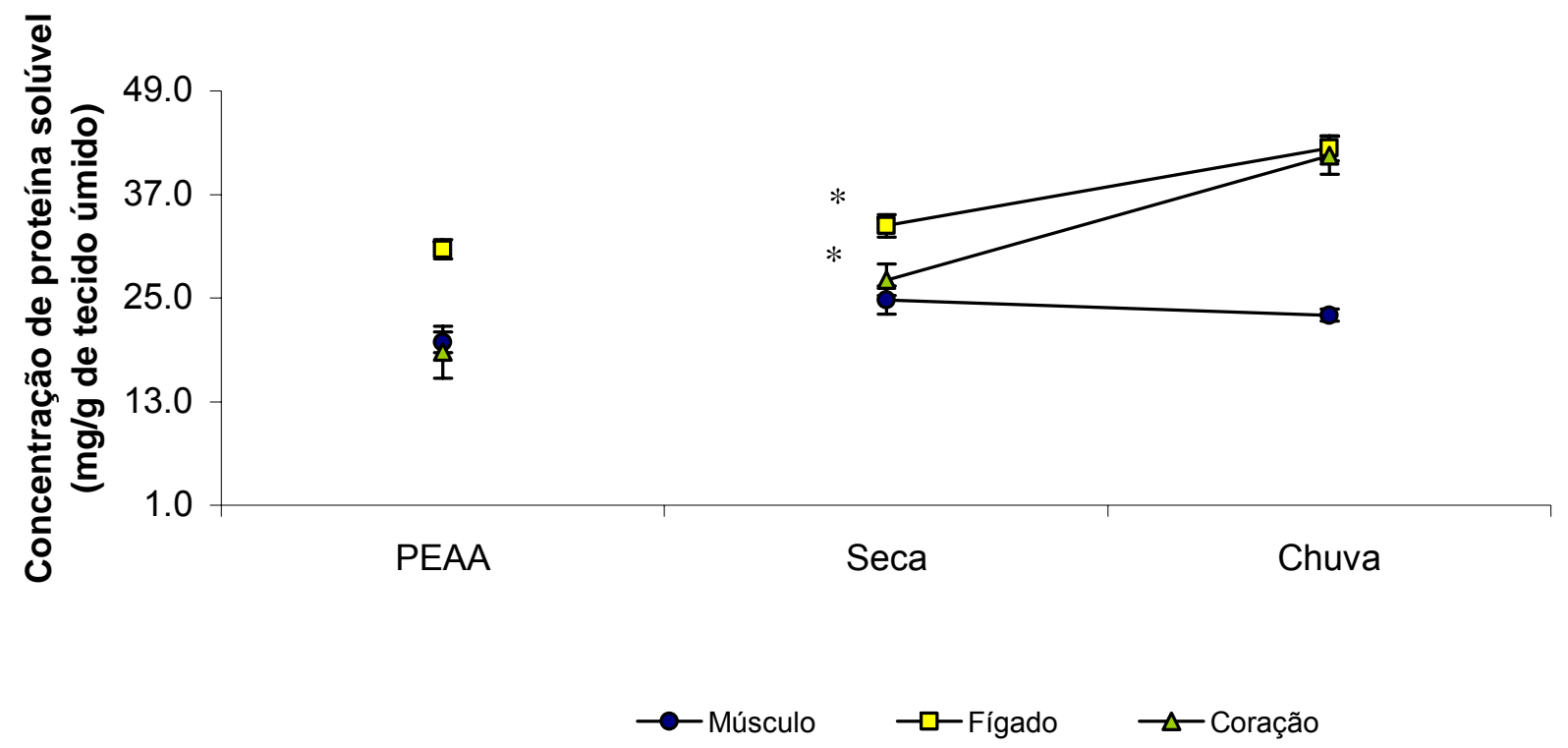

Figura 11. Concentração de proteína solúvel nos músculos dos membros posteriores, coração e fígado de indivíduos de $P$. diplolistris coletados em diferentes estações. Os asteriscos representam valores significativamente diferentes. PEAA (Possível emergência ano atípico). 


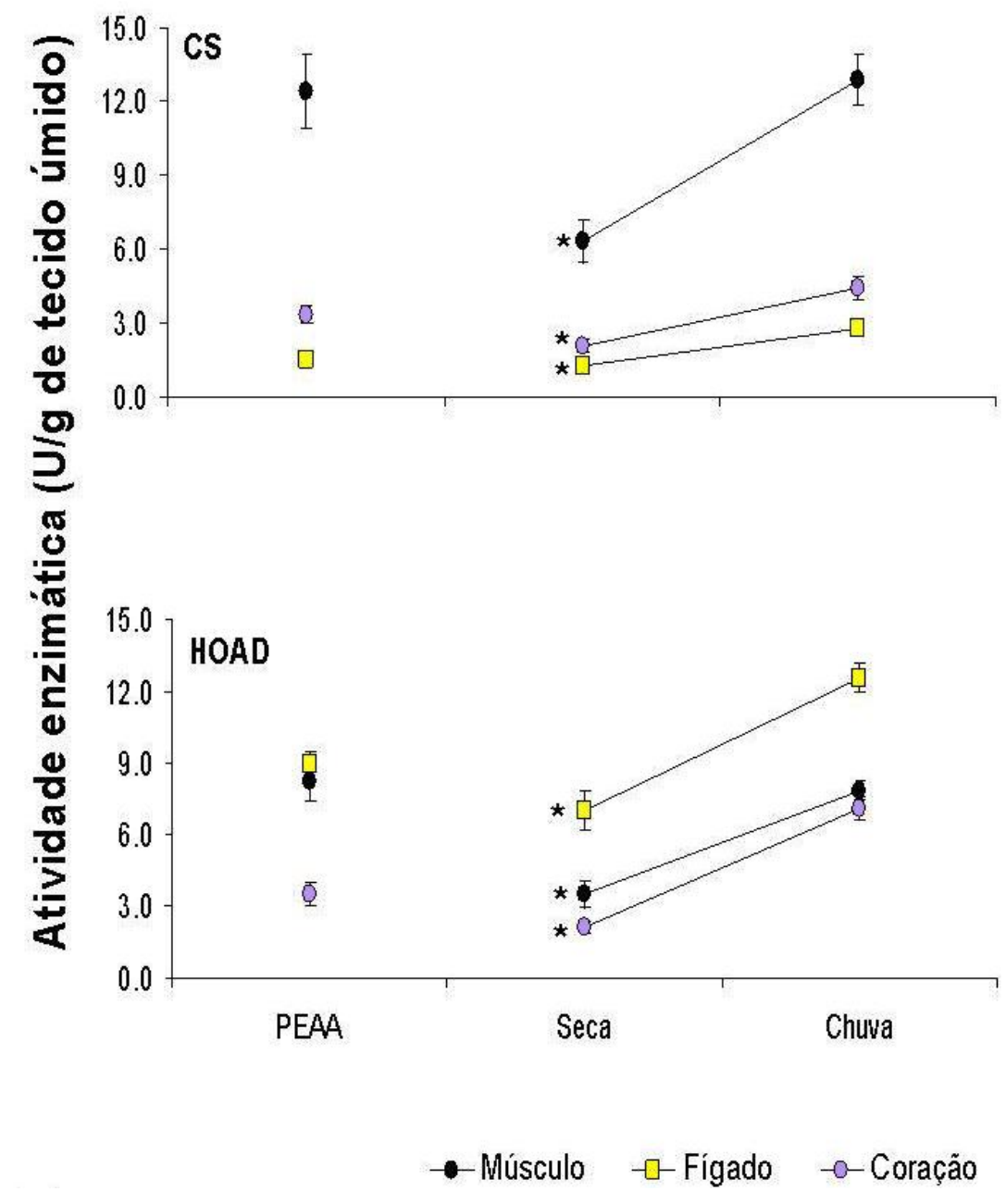

Figura 12. Atividade enzimática (U/g de tecido úmido) da citrato sintase (CS) e $\beta$-hidroxiacilCoA desidrogenase (HOAD) nos músculos dos membros posteriores, fígado e coração de animais coletados em diferentes estações do ano. Os valores representam a média e o erro padrão, para 10 indivíduos em cada estação. Em alguns pontos as barras de erro estão abaixo dos limites dos símbolos onde não é possível sua visualização. Os valores significativamente diferentes da seca são representados por asteriscos. 


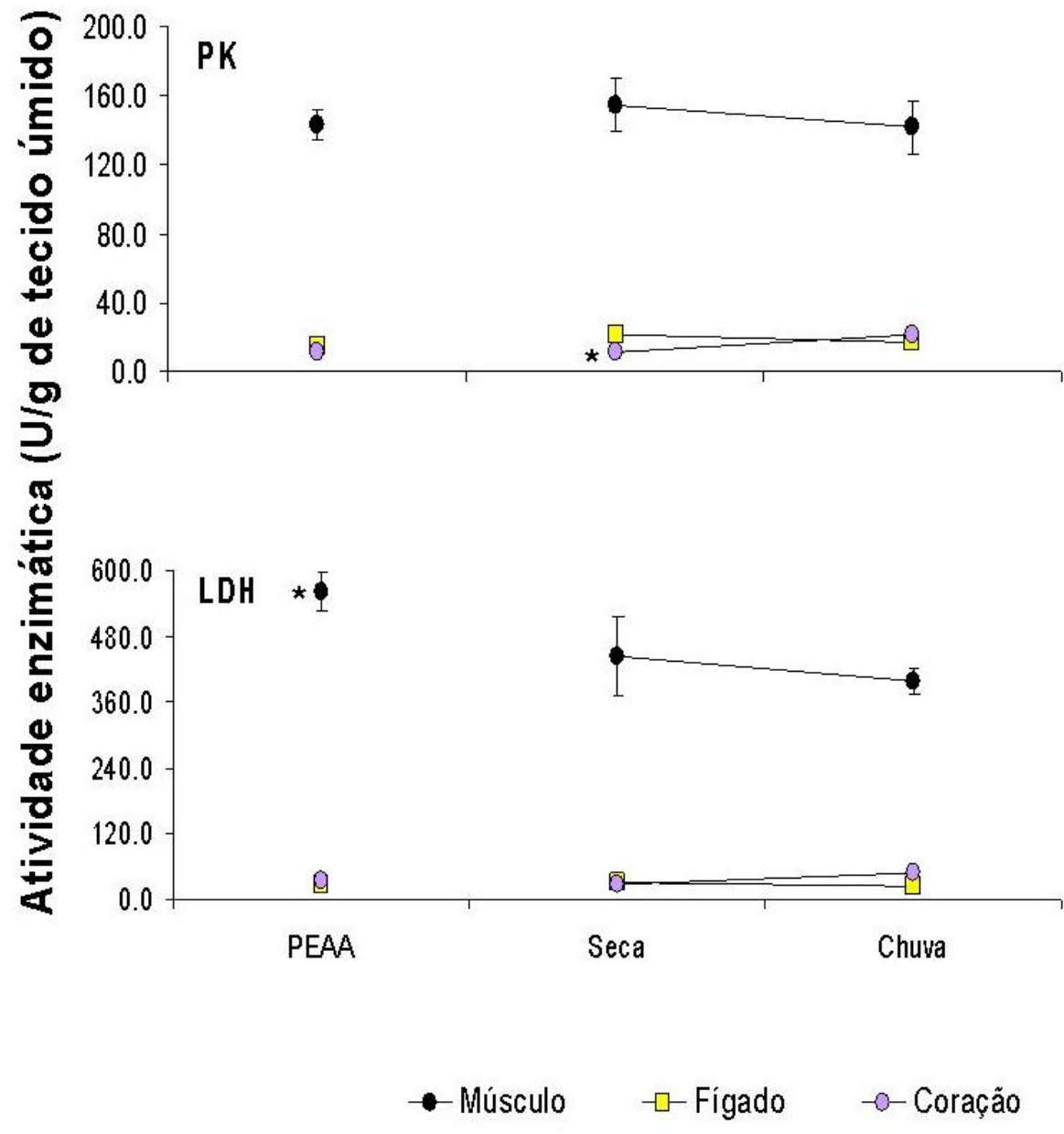

Figura 13. Atividade enzimática (U/g de tecido úmido) da piruvato quinase (PK) e lactato desidrogenase (LDH) nos músculos dos membros posteriores, fígado e coração de animais coletados em diferentes estações do ano. Os valores representam a média e o erro padrão, para 10 indivíduos. Em algumas figuras as barras de erro estão abaixo dos limites dos símbolos onde é possível a visualização. Os valores significativamente diferentes da seca são representados por asteriscos. 


\section{Discussão}

\subsection{Características do microhábitat e do comportamento de $P$. diplolistris}

O ambiente onde $P$. diplolistris foi coletado apresenta um índice pluviométrico baixo, de aproximadamente $300 \mathrm{~mm}$ por ano, com chuvas imprevisíveis e podendo ou não ocorrer durante os primeiros meses do ano (AB'SABER, 1974). Embora este hábitat possa ser considerado inóspito, os locais onde $P$. diplolistris constrói seus abrigos são caracterizados por temperatura moderada e relativamente constante. Em contraste, nos locais observados por Ruibal e colaboradores (1969), ocorre uma mudança significativa na temperatura do abrigo de Scaphiopus hammonii ao longo das estações do ano, as quais oscilaram de 7 a $24,4^{\circ} \mathrm{C}$. Em abrigos para outra espécie do mesmo gênero (S. couchii), as mudanças sazonais de temperatura foram comparativamente menores, variando de 14,5 a $23,8^{\circ} \mathrm{C}$ (SHOEMAKER et al., 1969). Nos abrigos de Cyclorana australis, a variação anual de temperatura foi de 19,9 a $25^{\circ} \mathrm{C}$. Então, pelo menos certas regiões da Caatinga parecem fornecer condições de microhábitat moderadas, do ponto de vista da ecologia termal. Mais ainda, há a possibilidade de que ajustes comportamentais contribuam para a ocupação de microhábitats ainda mais estáveis (TRACY et al., 2007).

Indivíduos de $P$. diplolistris foram encontrados em profundidades menores de $20 \mathrm{~cm}$, o mesmo foi observado com esta mesma espécie em dunas próximas ao Rio São Francisco na Bahia (CARVALHo \& BAILEY, 1948). Esse também parece ser o caso de certas espécies de Cyclorana, ou até maiores de $80 \mathrm{~cm}$, como relatado para Scaphiopus. Dada a variação na profundidade parece plausível que diversos gradientes ecológicos associados a 
profundidade sejam importantes para $P$. diplolistris, espécie que escava rapidamente a partir da superfície (veja algo relacionado em RUIBAL et al., 1969). Já durante a estação chuvosa, os animais permanecem enterrados no solo, perto de corpos de água temporários formados em depressões no solo ou em pedras, ou próximos de reservatórios permanentes (como os açudes), em profundidades que variaram de 5 a $10 \mathrm{~cm}$.

É possível que a escolha do microhábitat geral para a estivação seja ativamente selecionada pela espécie, dado que na área preliminarmente amostrada no leito do rio, só foram encontrados indivíduos próximos à cacimba. Nesse local, há chances de ocorrer um nível mais elevado de água subterrânea, quando comparado a outros locais próximos. Mais ainda, isso poderia ser verdade para outras espécies que na seca também são encontradas enterradas próximas à cacimba durante a estiagem, como Proceratophrys cristicepis e Physalaemus sp. Algo semelhante foi descrito para anuros no gênero Scaphiopus, que quando estivam no sudeste do Arizona (EUA), são facilmente encontrados em locais próximos aos tanques construídos para a criação de gado, onde a umidade do solo é mais elevada (McClanahan et al., 1994). Também Scaphiopus couchii, do deserto do Colorado (EUA), enterram-se em locais com características semelhantes, incluindo proximidade de vegetação e disponibilidade de água subterrânea. Além disso, $P$. diplolistris parece ter um comportamento compatível com o descrito para Scaphiopus couchii, que consiste em enterrar-se e reproduzir-se em locais diferentes. Parece que $P$. diplolistris escolhe abrigos com disponibilidade aparentemente maior de água e com menores variações de temperatura durante a estação seca, como reportado para S. couchii (MAYHEW, 
1965). Mais ainda, Scaphiopus hammondii, é encontrado em solo arenoso durante o inverno, enquanto no verão, que correspondente à estação chuvosa, é encontrado em solo argiloso próximo a corpos de água (SEYMOUR, 1973b).

Nos locais onde foram encontrados $P$. diplolistris, a umidade relativa no solo esteve próxima a 90\%, em profundidades maiores que $70 \mathrm{~cm}$. Algumas medidas de potencial hídrico indicam que a umidade disponível para as diferentes espécies pode variar muito, dependendo do local, e influenciar o comportamento de enterrar-se e formar casulo (RuIBAL et al., 1969). Nos abrigos de $P$. diplolistris observados, a umidade nas primeiras semanas após o termino das chuvas ainda era relativamente alta permitindo aos animais que enterrem-se em profundidades próximas à superfície logo após o final das chuvas. Os indivíduos de $P$. diplolistris podem, aparentemente, migrar verticalmente no solo acompanhando a diminuição no nível de água. Tal possibilidade é corroborada pela tendência dos animais de estarem em profundidades maiores com a diminuição da umidade no solo, e pelas características da sua fisiologia (ver páginas 29 e 30). Finalmente, mediante o trabalho de campo, confirmou-se que estes animais se tornam prontamente ativos assim que estimulados.

Sapos geralmente perdem água facilmente pela superfície da pele quando em contato com um ambiente com baixo potencial hídrico (SHOEMAKER et al., 1992), mas essa permeabilidade também garante a captação de água. Esse pode ser um dos motivos pelos quais $P$. diplostris foi encontrado em profundidades cada vez maiores no decurso temporal da estação seca. Os modelos de Agar, enterrados em diferentes níveis nos sítios de estivação de $P$. diplolistris revelaram que, quanto maior a profundidade, menor a perda de 
água. Esta medida serve como hipótese nula sobre o que possivelmente ocorre com os animais estivando, isso admintindo-se que não haja outro mecanismo (comportamental ou fisiológico) que regule a troca de água com o meio. Dessa forma, os animais enterrados mais próximos à superfície estariam sujeitos a uma maior desidratação e a maior capacidade de hidratação. Adicionalmente, todos os indivíduos de $P$. diplolistris coletados durante a estação seca continham urina na bexiga, diferentemente dos animais coletados na estação chuvosa, os quais estavam com a bexiga vazia. Outros anuros estivadores podem estocar o equivalente a $60 \%$ do seu peso corpóreo em água na bexiga, além de serem capazes de reabsorvê-la durante o acirramento da estação seca (MAIN \& BENTLEY, 1964).

Nos locais onde os indivíduos de $P$. diplolistris foram encontrados, há mudanças significativas na concentração de oxigênio do solo quando a profundidade é maior que $75 \mathrm{~cm}$. Mesmo assim, não é possível caracterizar tal ambiente como sendo hipóxico para anuros, pelo contrário, a diminuição no teor de oxigênio no solo ocorre de modo bastante sutil, sendo que a $150 \mathrm{~cm}$ a concentração de oxigênio chega a 98,71\% daquela encontrada na superfície. Este valor observado no solo arenoso da Caatinga é consideravelmente distante do valor de $86,91 \%$ encontrado no ambiente que Scaphiopus couchii utiliza durante a estivação (Figura 05, mas veja também SEYMOR, 1973c). Então, o gradiente de oxigênio encontrado parece ser ecologicamente irrelevante em termos de fisiologia da estivação, pois não varia de modo marcante no intervalo das profundidades estudadas, onde usualmente são encontrados os animais. Seymour (1973b) verificou que Scaphiopus hammondii e S. bombifrons enterrados a $70 \mathrm{~cm}$ de profundidade no deserto do 
Arizona estavam em um ambiente com a concentração de oxigênio maior que 20,8\%, mas Scaphiopus couchi já foi encontrado em ambientes com cerca de 18,2\% de oxigênio. Apesar de ser esta uma diminuição expressiva nas condições do microhábitat de S. couchii, este aspecto pareceu não provocar efeitos prejudiciais ao animal durante a fase de estivação (SEYMOUR, 1973b). O solo em que S. couchii é encontrado possui aparentemente, partículas de areia menores, deixando o solo mais compactado (SEYMOUR, 1973b). Sapos desta espécie norte-americana apresentam uma depressão de quase $85 \%$ do consumo de oxigênio durante a fase de seca (BICKLER \& BUCK, 2007). Por vezes, estes animais estão submetidos a um ambiente com uma concentração de oxigênio menor do que o verificado para $P$. diplolistris, que apresenta uma depressão do consumo de oxigênio da ordem de $50 \%$ em relação aos valores normais de repouso, sendo que a estivação, neste caso, ocorre em condições muito próximas à da normóxia.

\subsection{Ajustes metabólicos na estivação de Pleurodema diplolistris}

\subsubsection{Desempenho locomotor e taxa metabólica}

Períodos prolongados de inatividade podem comprometer o tecido muscular, causando atrofia (ВоотH, 1982). Apesar dos indícios desse trabalho sugerirem que indivíduos de $P$. diplolistris se movem ao menos verticalmente no solo onde estão enterrados a procura de microhábitats com maior disponibilidade hídrica, isso não exclui a priori a possibilidade de que períodos mais prolongados de inatividade possam afetar a estrutura e o funcionamento dos tecidos musculares (HUDSON \& FRANKLIN, 2002b; HUDSON et. al., 2007; JAMES, 2009). Dessa forma, o presente trabalho preocupou-se em verificar a 
influência da fase de estivação sobre o desempenho locomotor de $P$. diplolistris em comparação aos animais da estação chuvosa. Em linhas gerais, os indivíduos de $P$. diplolistris se locomoveram mesmo quando retirados dos abrigos no auge da estação seca, e há um contraste entre $P$. diplolistris e outros anfíbios estudados que também podem ser considerados responsivos. Por exemplo, sapos S. couchii respondem a diversos estímulos e mudam de posição durante a estivação, mas a abertura dos olhos ocorre somente após 15 a 30 minutos da saída do estado de torpor, quando finalmente os animais se tornam completamente alertas (MCCLANAHAN, 1967).

A preservação do músculo esquelético durante a estivação poderia ser uma característica de anuros estivadores, por exemplo, em sapos Cyclorana alboguttata, nos quais a função muscular é preservada durante os três primeiros meses de estivação. Mais ainda, a velocidade de locomoção dessa espécie não é significativamente alterada entre animais estivando durante três meses e em atividade (HUDSON \& FRANKLIN, 2002a). Em P. diplolistris, a velocidade do deslocamento terrestre aumentou cerca de $50 \%$ na estação chuvosa em comparação com os animais amostrados durante a seca. No caso de C. alboguttata, a locomoção foi medida através da velocidade do nado, o que é ecologicamente relevante para a espécie, uma vez que esta passa a maior parte da estação chuvosa na água após emergirem dos locais dos abrigos. Não ocorrem mudanças significativas no tamanho e na distribuição do tecido conjuntivo muscular depois de 4 ou 9 meses de estivação (HUDSON \& FRANKLIN, 2003; SYMONDS et al., 2007), e os indivíduos sofrem pouco prejuízo na função muscular após 15 meses de estivação induzida em laboratório (LAVIDIS et al., 2008). Note que em ratos, para efeito de comparação com 
mamíferos, a atrofia do tecido muscular esquelético já é significativa após 4 dias de imobilização (SOARES et al., 1993).

A depressão metabólica observada em $P$. diplolistris estivando é relativamente inferior a de outros exemplos de anuros estivadores que têm sido estudados, pois há reportes de quase $85 \%$ de depressão do metabolismoo aeróbio para algumas espécies (GUPPY \& WITHERS, 1999; GUPPY et al., 1994; HAND \& HARDEWig, 1996; HochachKa \& SOMERo, 2002; Storey, 2002). Ainda assim, a redução no consumo de oxigênio de $P$. diplolistris durante a estiagem certamente leva a uma redução na taxa de utilização dos estoques energéticos além de uma diminuição na taxa de desidratação, como consequência da diminuição da respiração cutânea e da perda evaporativa de água.

Sem dúvida, a fase que antecede a estiagem é de fundamental importância para os indivíduos de $P$. diplolistris, uma vez que é neste momento que os estoques dos principais substratos energéticos são repostos. Com a diminuição da taxa metabólica, há uma consequente redução da taxa de uso desses compostos. Como não foram coletados animais no momento em que estes ingressaram no estado hipometabólico, no início da fase de estiagem, não é possível afirmar com precisão sobre o tamanho relativo das reservas de lipídeos e carboidratos e como estes foram utilizados na manutenção do balanço energético durante esta transição. Contudo, estimativas feitas a partir da taxa metabólica durante a estivação em outros modelos, como no caso de sapos S. couchii e S. multiplicatus, indicam que os animais podem permanecer por alguns anos sobrevivendo às custas de suas reservas internas de lipídeos e carboidratos (GEHLBACH, 1973; SMITH, 1950; JONES, 1980). 
Em anuros estivadores ocorre um aumento na quantidade de corpos gordurosos durante a fase de alimentação, pois os animais precisam de energia não só para sobreviver durante a seca, mas também para a reprodução que é explosiva e ocorre logo no início da chuva. Dados para Scaphiopus couchii indicam que, durante o estado hipometabólico, a gordura acumulada nos diversos tecidos é responsável pelo suprimento de até $94 \%$ da energia requerida para a manutenção do balanço energético (MCCLANAHAN, 1967). Contudo, parece consenso entre diversos autores que a manutenção do estado hipometabólico com o uso das reservas endógenas de substratos energéticos não é um grande desafio, dada a redução geral da taxa metabólica (CARVAlHo et al., 2009). Vale notar também, que em indivíduos de $P$. diplolistris coletados logo no início das chuvas, durante a estação reprodutiva, não se encontrou alimento no trato gastrointestinal. Apenas em um pequeno grupo de animais coletados no meio da estação chuvosa verificou-se a presença resquícios de alimentos no estômago e no intestino. Essas informações corroboram a idéia de que os indivíduos provavelmente utilizam suas próprias reservas energéticas para sustentar esta fase reprodutiva, havendo um forte compromisso entre a taxa de utilização desses compostos e a capacidade para a atividade e reprodução.

\subsubsection{Reservas energéticas e atividade enzimática}

Em P. diplolistris ocorreram mudanças significativas nas concentrações dos principais substratos energéticos nas duas marcantes estações do ano. As concentrações de lipídeos totais e glicogênio estavam menores tanto nos músculos dos membros posteriores, quanto no fígado, nos animais capturados 
logo no início da estação chuvosa. Além disso, a concentração de glicose nos músculos esqueléticos foi cerca de 58,3\% menor em comparação aos dados obtidos na estação chuvosa, mudança esta coincidente com a diminuição dos níveis de glicogênio nesta última fase, o que sugere a mobilização desses estoques para o fornecimento de substrato à produção de ATP para a atividade (ver Figura 10). De modo semelhante, a massa relativa de corpos gordurosos, assim como as concentrações de lipídeos totais nos músculos dos membros posteriores e no fígado, foi significativamente reduzida nos animais que iniciavam a fase reprodutiva. Este padrão de alterações corrobora a idéia de que os indivíduos de $P$. diplolistris devem emergir do estado hipometabólico e ingressar na atividade reprodutiva antes mesmo de alimentarem-se e formarem novos estoques.

Como discutido anteriormente, os indivíduos de $P$. diplolistris observados durante a estivação não apresentaram vestígios recentes de alimento no estômago e no intestino. Animais desta mesma espécie foram encontrados na Bahia, onde também permaneceram ativos apenas durante a estação chuvosa, não havendo registros de forrageamento durante a estiagem (SANTOS et al., 2003). Mesmo após as primeiras chuvas de fraca intensidade, não foram encontrados animais desta espécie com alimento no trato gastrointestinal, diferente do observado para sapos S. hammondii, os quais aparentemente alimentam-se imediatamente após a primeira chuva da estação ou mesmo antes (RUIBAL, 1969).

Os indivíduos de $P$. diplolistris coletados durante a possível emergência em um ano atípico, parecem mais próximos daqueles coletados durante a seca. Do ponto de vista de certas variáveis metabólicas, eles aparentam ter 
emergido e alimentado-se. Este é o caso, por exemplo, das concentrações de substratos energéticos. Tanto as concentrações de carboidratos quanto de lipídeos totais neste grupo de animais assemelham-se ao padrão observado para os animais analisados durante a estiagem. Além disso, os animais coletados nesta fase também não continham vestígios de alimentos no estômago e intestino. Diversas hipóteses poderiam explicar o padrão observado, mas o conjunto de dados obtidos mais os relatos dos moradores sobre o padrão de chuvas corroboram a ideia de uma emergência curta, sem reprodução. Então, algum nível de precipitação possivelmente ocorreu durante a estiagem e os animais podem ter emergido de seus abrigos e se alimentado, elevando o nível de seus estoques energéticos. Vale mencionar que no local onde $P$. diplolistris foi encontrado, não chove o suficiente em alguns anos para que os açudes locais encham, mas essa pequena chuva parece suficiente para estimular a reprodução dos animais ou da grande maioria dos indivíduos. Segundo McClanahan (1967), S. hammondii sai para forragear pouco antes das chuvas fortes, alimenta-se e volta a enterrar-se a profundidades menores. Em outros modelos, como Cyclorana alboguttata ocorre ainda uma diminuição na massa do intestino delgado durante a estivação, mas essa perda é rapidamente recuperada quando o animal volta a alimentar-se momentos antes da reprodução (CRAMP \& FRANKLIN, 2003; CRAMP et al., 2005). Também em Cyclorana australis verificou-se que precipitações que atingissem aproximadamente $50 \mathrm{~mm}$ eram suficientes para que os animais emergissem do abrigo, enquanto volumes abaixo de $20 \mathrm{~mm}$ não eram suficientes para estimulá-los à atividade (TRACY et. al., 2007). 
Com a baixa atividade metabólica observada durante a estivação de $P$. diplolistris, e uma queda significativa na taxa de consumo de oxigênio, é provável que a atividade cardíaca também esteja reduzida, dado o acoplamento que existe entre taxas respiratórias e circulação sanguínea. A relativa baixa concentração protéica no coração destes animais durante a estivação corrobora tal hipótese, uma vez que este evento pode levar a uma menor capacidade contrátil em condições onde a demanda energética pelos tecidos, de um modo geral, é reduzida. Contudo, este aspecto da biologia de anuros tem sido muito pouco estudado, sobretudo no contexto da estivação em condições tão peculiares (HELDMAIER et al., 2004).

A concentração de proteínas nos músculos dos membros posteriores não sofreu alterações marcantes ao longo das estações seca e chuvosa, sendo cerca de 19,7\% menor nos animais coletados na estação atípica em relação aos animais na fase de seca e chuva. A síntese de proteínas é, sem dúvida, um dos processos mais custosos do ponto de vista energético e, em muitos modelos de depressão metabólica, tem observado-se uma queda acentuada neste processo durante a fase hipometabólica (HAND \& HARDEWING, 1996). uso de proteínas como substrato energético é de fato bastante reduzido durante a fase de estivação em Cyclorana platycephalus (VAN BEURDEN, 1980), mas que em condições de estresse hídrico pode aumentar consideravelmente, como relatado em Scaphiopus couchii (McCLANAHAN, 1972). Este processo parece estar relacionado com a expressão de uma série de genes que controlam a expressão de outros genes envolvidos na regulação de vias energéticas, especialmente aquelas que levam à formação de espécies reativas de oxigênio (HUDSON et al. 2008 e 2006). A manutenção dos níveis 
protéicos em $P$. diplolistris podem ainda ter relação com a manutenção da capacidade de deslocamento do animal, como discutido anteriormente sobre o desempenho locomotor desses animais durante a estivação.

A depressão da CS e da HOAD na fase de estiagem de $P$. diplolistris é um indicador de que a capacidade das vias aeróbias deva estar diminuída, como é visto tanto no coração, quanto no fígado e nos músculos dos membros posteriores. Apesar das evidências indicarem que a estivação de $P$. diplilistris ocorre em condições onde a disponibilidade de oxigênio não é um fator limitante, há fortes indícios de que os passos catalisados por essas enzimas (HOAD e CS) acompanhem a diminuição observada na taxa metabólica desses animais. Resultados semelhantes a estes foram vistos em S. couchii, nos quais a capacidade aeróbia nos músculos esqueléticos esteve reduzida durante a estivação (COWAN \& STOREY, 2002, mas veja também ST-PIERRE \& BOUTILIER, 2001). Apesar de muitos anfíbios anuros serem mais dependentes de vias independentes do oxigênio para a manutenção da produção de ATP durante a típica locomoção por saltos neste grupo, em algumas espécies as vias aeróbias apresentam uma correlação com hábito locomotor sustentado, como visto em algumas espécies de bufonídeos e dendrobatídeos (BENNETT, 1974; WELLS, 2007). Como visto, em $P$. diplolistris há uma redução significativa da capacidade para a locomoção durante a estivação e, como estes animais são capazes de deslocarem-se por longas distâncias, a diminuição na capacidade aeróbia (como na atividade da CS) pode, de certa forma, corroborar tal resultado. Esta mesma linha de raciocínio pode ser considerada para as mudanças que acontecem no tecido muscular cardíaco, no qual a diminuição da atividade da CS pode estar ligada a uma redução geral na atividade do 
coração. Quando os indivíduos de P. diplolistris retomam a atividade no início da estação chuvosa, o aumento significativo na atividade da HOAD no tecido hepático pode estar relacionado com o maior uso dessas reservas para a manutenção da homeostase energética nesta fase, como também observado na dormência sazonal de lagartos teiú (SouzA et al., 2004). Cabe ainda salientar que os machos de $P$. diplolistris, após emergirem de seus abrigos na estação chuvosa, iniciam a fase reprodutiva com uma intensa taxa de vocalização, que pode durar mais que 4 horas em um dia (observações pessoais). A vocalização é, talvez, uma das atividades mais energeticamente custosas para os animais (Wells, 2001; NAVAS et al., 2008; CARVALHO et al., 2008) que se encontram em um momento crítico, quando a demanda energética é aumentada e a alimentação ainda não começou. A dependência do uso de lipídeos torna-se ainda mais importante para os animais sob estas condições.

Aparentemente, não ocorrem alterações marcantes na capacidade da via glicolítica no fígado durante a estivação em $P$. diplolistris, uma vez que as atividades das $\mathrm{PK}$ e da LDH mantiveram-se praticamente constantes nos grupos observados. Constatou-se em outras espécies de anuros, uma queda na atividade da LDH durante a fase de dormência, como em Rana ridibunda, a qual exibe uma marcada depressão metabólica evidenciada pela diminuição do consumo de oxigênio (MICHAELIDIS et al., 2008). Já em S. couchii, a atividade da LDH no fígado diminui significativamente durante a fase de estiagem (Cowan et al., 2000). Os resultados obtidos em $P$. diplolistris sugerem que os passos catalisados pela PK e pela LDH não sejam alvo de regulação durante o ciclo entre as fases de estivação e atividade. Provavelmente, o hábito de 
deslocar-se no microhábitat à procura de locais com maior disponibilidade hídrica pode estar relacionado com estes achados. Certamente, uma investigação mais detalhada dos aspectos da fisiologia metabólica desses animais pode revelar a importância relativa desses ajustes sobre o balanço energético e a manutenção de certos níveis de atividade. 


\section{CONCLUSÃO}

O microhábitat para a estivação em Pleurodema diplolistris possui temperaturas próximas às encontradas na superfície durante a atividade reprodutiva e de forrageamento, umidade de $90 \%$ e concentração de oxigênio próxima a $21 \%$, valor próximo a um ambiente normóxico. Contudo, tal microhábitat favorável parece encontrar-se a diferentes profundidades, à medida que avança a estação seca. Assim, uma depressão metabólica moderada, ausência de casulo e preservação da capacidade locomotora parecem importantes na estratégia de estivação desta espécie.

A proposta anterior, derivada da abordagem ecológica, é corroborada pelos dados fisiológicos. Os padrões de alteração nas taxas de consumo de oxigênio e nas concentrações de lipídeos e glicogênio corroboram a hipótese de diminuição do metabolismo durante a fase de estiagem, enquanto a diminuição na concentração de proteínas cardíacas solúveis corrobora uma provável diminuição da atividade cardíaca durante a estação seca. Os tecidos estudados exibem baixa dependência da oxidação de lipídeos durante a estiagem e a capacidade aeróbia esteve reduzida, diferente da glicolítica, que se mostrou preservada. Entretanto, nos músculos dos membros posteriores não houve perda inicial de proteína, sugerindo a preservação da capacidade funcional do tecido durante esta fase, aspecto corroborado no nível organismal mediante testes da capacidade de locomoção. Assim sendo, o padrão de estivação de $P$. diplolistris pode ser considerado atípico, pelo menos quando comparado a outras espécies que já foram estudadas. A ausência de depressão da via anaeróbia é outro diferencial na estivação de Pleurodema diplolistris, pois diferentemente do que ocorre em outros estivadores estudados 
a atividade de algumas enzimas representativas da via glicolítica não diminui durante a dormência. 


\section{Referências Bibliográficas}

ABE, A.S. (1983) Observations on dormancy in tegu lizard Tupinambis teguixin (Reptilia, Teiidae). Naturalia (8): 235-239.

ABE, A.S. \& GARCIA, L.S. (1990) Changes in body fluids of the frog Leptodactylus fuscus during aestivation (Anura, Leptodactylidae). Revista brasileira de biologia 50(1): 243-247

AB'SABer A.N. (1974) O domínio Morfoclimático Semi-árido das Caatingas Brasileiras. Geomorfologia (43):1-32.

BASTOS R.P. \& ABE A. (1998) Dormancy in the Brazilian horned toad Ceratoprys aurita (Anura/Lepdodactylidae). Ciência e Cultura (50):68-69.

BENNETT, A.F. (1974) Enzymatic correlates of activity metabolism in anuran amphibians. American Journal of Physiology (226): 1149-1151.

BENTLEY, P.J. (1966) Adaptations of Amphibia to Arid Environments. Science 619-623.

BICKLER, P.E.\& BUCK, L.T. (2007) Hypoxia tolerance in reptiles, amphibians e fishes:

Life with variable oxygen available. Annual Reviews Physiology (69): 145-170.

BootH, D.T. (2006) Effect of soil type on burrowing behavior and cocoon formation in the green-striped burrowing frog, Cyclorana alboguttata. Canadian Journal of Zoology 84 (6): 832-838.

BоотH, F. (1982). Effect of limb immobilization on skeletal muscle. Journal of Applied Physiology (52): R1113-R1118.

Carvalho, J.E.; NaVAs, C.A. and PereiRA, C.P. (2009) Energy and water in aestivating amphibians (in press). In: Carlos Arturo Navas; Jose Eduardo de Carvalho. (Org.). Aestivation: Molecular and Physiological Aspects. Heildelberg: SpringerVerlag.

Carvalho, A.L. \& Bailey, J.R. (1948) Sobre os hábitos e ecologia de "Pleurodema diplolistris" (Peters) (Amphibia, Anura). Revista Brasileira de Biologia (8):261264.

Cartledge V.A., Withers P.C., Thompson G.G. And McMaster K.A. (2006a) Water relations of the burrowing sandhill frog, Arenophryne rotunda (Myobatrachidae). Journal of Comparative Physiology Part B (176): 295-302.

Cartledge V.A., Withers P.C., McMaster K.A., Thompson G.G and Don BradshaW S. (2006b) Water balance of field-excavated aestivating Australian desert frogs, the cocoon-forming Neobatrachus aquilonius and the non-cocooning Notaden nichollsi (Amphibia: Myobatrachidae). Journal of experimental biology (209): 3309-3321. 
COWAN, K.J. \& STOREY, K.B. (2002) Urea and KCl have differential effects on enzyme activities in liver an muscle of aestivating versus noestivating species. Biochemical Cellular Biology (80): 745-755

CoWAN, K.J., MacDonald, J.A., StOReY, J.M. and StOREY, K.B. (2000) Metabolic reorganization and signal transduction during estivation in the spadefoot toad. Experimental Biology Online 5(1): 1-25.

Cramp, R.,FrankLIN, C.E. and MeYER E.A. (2005) The impact of prolonged fasting during aestivation on the structure of the small intestine in the green-striped burrowing frog, Cyclorana alboguttata. Acta Zoologica (Stockholm) (86): 13-24.

CRAMP, R. \& FRANKLIN, C.E. (2003) Is Re-Feeding Efficiency Compromised by Prolonged Starvation During Aestivation in the Green Striped Burrowing Frog, Cyclorana alboguttata? Journal of Experimental Zoology (300A): 126-132.

Duellman, W.E., TrueB, L. (1986). Biology of amphibians. McGraw-Hill Book Company, New York.

Fernandes, A. (1999). Província das Caatingas ou nordestina. Anais da Academia Brasileira (71): 299-310.

FlANigAN, J. E.; WitheRS, P. C. \& GuPPy, M. (1991) In vitro metabolic depression of tissues from the aestivating frog Neobratrachus pelobatoides. Journal of Experimental Biology (161): 273-283.

Folch, J.; Lees, M. \& Sloane Stanley, G.H. (1957) A simple method for the isolation and purification of total lipids from animal tissues. Journal of Biology Chemistry (226): 497-509.

Fuery, C.J., Withers, P.C., HobBS, A.A., GupPy, M., (1998) The role of protein synthesis during metabolic depression in the Australian desert frog, Neobatrachus centralis. Comparative Biochemistry and Physiology Part A (119) 469-476.

FRINGS, C.S. \& DUNN, R.T. (1970) A colorimetric method for determination of total serum lipids based on the sulfo-phospho-vanilin reaction. American Journal of Clinical Path (53): 89-91.

FRINGS, C.S.; FEndley, T.W.; DUNN, R.T. \& QUEEN, C.A. (1972) Improved determination of total serum lipids by the sulfo-phospho-vanilin reaction. Clinical Chemistry (18): 673-674.

GeHLBACH, F.R., GORDON, R. and JORDAN, J.B. (1973) Aestivation of the Salamander, Siren intermedia. American Midland Naturalist (89): 455-463.

GuPPY, M. (2004) The biochemistry of metabolic depression: a history of perceptions. Comparative Biochemistry and Physiology Part B (139): 435-442.

GuPPY, M. \& WiTHERS, P. (1999) Metabolic depression in animals: physiological perspectives and biochemical generalizations. Biological Reviews (74): 1-40. 
Guppy, M, FueRY, C.J. and Flanigan, J.E. (1994). Biochemical principles of metabolic depression. Comparative Biochemistry and Physiology 109B (2/3): 175-189.

HAND, S.C. \& HARDEWING, I. (1996) Down regulation of cellular metabolism during environmental stress: mechanisms and implications. Annual Review of Physiology (58): 539-563.

Harvey, L., Propper, C. R., Woodley, S.K. and Moore, M.C., (1997) Reproductive Endocrinology of the Explosively Breeding Desert Spadefoot Toad, Scaphiopus couchii. General and Comparative Endocrinology (105): 102-113.

Heldmaier, G., Ortmann, S., and Elvert R. (2004) Natural hypometabolism during hibernation and daily torpor in mammals Respiratory Physiology \& Neurobiology (141): 317-329.

HOCHACHKA, P.W. \& Guppy, M. (1987). Metabolic Arrest and the Control of Biological Time. (University Press, Harvard).

HochACHKA, P.H. \& SOMERO, G.N. (2002) Biochemical Adaptation: Mechanisms and Process in Physiological Evolution. Oxford University Press.

HOCHACHKA, P.H. \& SOMERO, G.N. (1984) Biochemical Adaptation. Princeton University Press.

HöDL, W. (1992) Reproductive behavior in the neotropical foam-nesting frog Pleurodema diplolistris (Leptodactylidae). Amphibia-Reptilia (13): 263-274.

HudSON, N.J \& FRANKLIN, C.E. (2002a) Effect of aestivation on muscle characteristics and locomotor performance in the Green-striped burrowing frog, Cyclorana alboguttata. Journal of Comparative Physiology B (172):177-182.

HUDSON, N.J \& FRANKLIN, C.E. (2002b) Maintaining muscle mass during extended disuse: aestivating frogs as a model species. The Journal of Experimental Biology (205): 2297-2303.

HUdSON, N.J \& FRANKLIN, C.E. (2003) Preservation of three-dimensional capillary structure in frog muscle during aestivation Journal of Anatomy (202): 471-474.

Hudson, N.J.; Harper, G.S.; Allingham, P.G.; Franklin, C.E. Barris, W. and LEHNERT S.A. (2007) Skeletal muscle extracellular matrix remodeling after aestivation in the green striped burrowing frog, Cyclorana alboguttata. Comparative Biochemistry and Physiology A (146): 440-445.

Hudson, N.J., LeHNERT,S.A., INGHAM, A.B., SYMONDS, B., FRANKLIN, C.E. and HARPER G.S. (2006) Lessons from an estivating frog: sparing muscle protein despite starvation and disuse". American Journal of Physiology. Regulatory, Integrative and Comparative Physiology (290): R836-R843. 
Hudson, N.J., LAVIDIS A.N., CHOY, P.T. and FRANKLIN, C.E. (2005) Effect of prolonged inactivity on skeletal motor nerve terminals during aestivation in the burrowing frog, Cyclorana alboguttata. Journal of Comparative Physiology A (191): 373-379.

JAMES, R. S. (2009) Effects of aestivation on skeletal muscle performance (in press). In: Carlos Arturo Navas; Jose Eduardo de Carvalho. (Org.). Aestivation: Molecular and Physiological Aspects. 0 ed. Heildelberg: Springer-Verlag.

Jared, C., AntoniazzI, M.M., Navas, C.A., Katchburian, E., Freymüller,E., TAMBouRgI, D.V. and RodRIGUes, M.T. (2005) Head co-ossification, phragmosis and defense in the casque-headed tree frog Corythomantis greeningi. Journal of Zoology of London (265): 1-8.

JONES, R.M. (1980) Metabolic consequences of accelerated urea synthesis during seasonal dormancy of spadefoot toads, Scaphiopus couchii and Scaphiopus multiplicatus. Journal of Experimental Zoology (212): 255-267.

JøRGENSEN, C.B. (1997) 200 year of amphibian water economy: from Robert Townson to the present. Biology Reviews (72): 153-237.

JøRGENSEN, C.B. (1992) Growth and Reproduction. In: Environmental Physiology of the Amphibians. FEDER, M.E. \& BURGgREEN, W.W. (eds). Press for University of Chicago, pp. 439-466.

KLEPPLER, D. \& DECKER, K. (1984) Glycogen. In: Methods of Enzymatic Analysis. BeRgmeYER, H.U. (ed.) v.6. Weinheim, Verlag Chemie.

KNIGHT, J.A.; ANDERSON, S. \& RAWLE, J.M. (1972) Chemical basis of the sulfophospho-vanilin reaction for estimating total serum lipids. Clinical Chemistry (18): 199-202.

Kobelt, F. \& LinSENMAIR, K.E. (1995) Adaptations of the reed frog Hyperolius viridiflavus (Amphibia, Anura, Hyperoliidae) to its arid environment: VII. The heat budget of Hyperolius viridiflavus nitidulus and the evolution of optimized body shape. Journal of Comparative Physiology B (165):110-124.

KRISHNA (2004) Breeding ecology of a rare microhylid, Ramanella montana, in the forests of Western Ghats, India. Current Science (87): 80-82.

LAVIDIS, N.A.; HUdSON, N.J.; CHOY, P.T.; LEHNERT, S.A. and FRANKLIN, C.E. (2008) Role of calcium and vesicle-docking proteins in remobilizing dormant neuromuscular junctions in desert frogs. Journal of Comparative Physiology $A$ (194):27-37.

LoWry, O.H.; Rosen Brough, N.J.; FarR, A.L. and RandalLI, R. J. (1951) Protein measurement with the Folin phenol reagent. Journal of Biology Chemistry (193): 265-275.

MAIN, A.R. \& BentLeY, P.J. (1964) Water relations of Australian burrowing frogs and tree frogs. Ecology (45): 379-382. 
MAYHEW, W.W. (1965). Adaptations of amphibian, Scaphiopus couchii, to desert conditions. American Midland Naturalist (74): 95-109.

McClanahan, L.L.J., Ruibal, R. and ShOEMAKeR, V.H. (1994) Frogs and Toads in Desert. Scientific American (3) 64-70.

McClanahan, L.L.J., ShoemakeR, V.H. and RuibaL, R. (1976) Structure and Function of the Cocoon of a Ceratophryd Frog. Copeia (1): 179-185.

MCCLANAHAN, L.L.J. (1972) Changes in body fluid of burrowed spadefoot toads as a function of soil water potential". Copeia (2): 209-216.

MCClANAHAN, L.L.J. (1967) Adaptation of the spadefoot toad, Sacaphiopus couchii, to desert environments. Comparative Biochemistry and Physiology (20): 73-99.

Michaelidis, B., Kyriakopoulou-Sklavounm, P., Staikou, A., Papathanasiou, L. and KONSTANTINOU, K. (2008) Glycolytic adjustments in tissues of frog Rana ridibunda and land snail Helix lucorum during seasonal hibernation. Comparative Biochemistry and Physiology Part A (151) 582-589.

NAvAS, C.A., ANTONIAZZI, M.M., and JARED, C., (2004) A preliminary assessment of anuran physiological and morphological adaptation to the Caatinga, a Brazilian semi-arid environment. In: MORRIS, S., VOSLOO, A. (Eds.), Animals and Environments. Proceedings of the Third International Conference of Comparative Physiology and Biochemistry, vol. 1275. Elsevier, Cambridge and Oxford, pp. 298305.

NAVAS, C.A. \& ARAUJO, C. (2000) The use of Agar Models to Study Amphibian Thermal Ecology. Jounal of Herpertology 32 (2):330-334.

PAKAY, J.L., WithERS, P.C., HOBBS. A.A. \& GUPPY, M. (2003) In vivo dowregulation of protein synthesis in the snail Helix apersa during estivation. American Journal of Physiology - regulatory integrative and comparative physiology 283(1): 197204.

PARRISH, C.C. (1998) Determination of total lipids, lipid classes and fatty acids in aquatic samples. In: ARTS, M.T. \& WAINMAN, B.C. (eds.) Lipids in Freshwater Ecosystems. Spring-Verlag, NY. pp. 4-12.

Pinter, A.W., StoRey, K.B. \& UUtSCH, G.R. (1992) Estivation and Hibernation. In: Environmental Physiology of the Amphibians. FEDER, M.E. \& BURGgREEN, W.W. (eds). Press for University of Chicago, pp. 250-274.

RodRIGUES, M.T. (2003) Hepertofauna da Caatinga. In: Ecologia e Conservação da caatinga. Leal, I.R.; TABARELLI, M. \& SILVA, J.M.C. (eds). Editora Universitária da UFPE, pp. 181-236.

RomARIZ, D.A. (1996) Aspectos da vegetação do Brasil. 2 ed. São Paulo. 
RuIBAL, R.; TEVIS, L. \&. RoIG, V. (1969) The terrestrial ecology of the spadefoot toad Scaphiopus hammondii. Copeia (3): 571-584.

RYSER, J. (1989) Weight loss, reproductive output, and the cost of reproduction in the common frog, Rana temporaria Oecologia (78): 264-268.

SANTOS, J.W.A., DAmAsceno, R.P. and RochA, P.L. (2003) Feeding habitas of the frog Pleurodema diplolistris (Anura, Leptodactylidae) in Quartenary sand dunes of the Middle Rio São Francisco, Bahia, Brazil. Phyllomedusa 2(2):83-92.

SCHMUCK, R. \& LINSENMIR, K.E. (1997) Regulation of Body Water Balance in Reedfrogs (Superspecies Hyperolius viridiflaetus and Hyperolius murmorutus: Amphibia, Anura, Hyperoliidae) Living in Unpredictably Varying Savannah Environments. Comparative Biochemistry Physiology (118)A: 1335-1352.

SECOR, S.M. (2005) Phisiological responses to feeding, fasting and aestivaton for anurans. The Journal of Experimental Biology (208): 2595-2608.

SEYMOUR, S.R. (1973a) Physiological correlates of activity and burrowing in the spadefood toad Scaphiopus hammondii. Copeia (1): 452-460.

SEYMOUR, S.R. (1973b) Energy metabolism of dormant Spadefoot Toads (Scaphiopus). Copeia (3): 435-445.

SEYMOUR, S.R. (1973c) Gas exchange in Spadefoot Toads beneath the ground. Copeia (3): 452-460.

Shalan, A.G., Bradshaw, S.D., Withers, P.C., Thompson, G., Bayomy, M.F.F., BRADSHAW, F.J. and STEWART, T. (2004) Spermatogenesis and plasma testosterone levels in Western Australian burrowing desert frogs, Cyclorana platycephala, Cyclorana maini, and Neobatrachus sutor, during aestivation. General and Comparative Endocrinology (136): 90-100.

SHOEMAKER, V.H. (1964) The effects of dehydration on electrolyte concentrations in a toad, Bufo marinus. Comparative Biochemistry and Physiology 13(3): 261-271.

ShoemakeR, V.H., McClanahan, L. and Ruibal, R. (1969) Seasonal Changes in Body Fluids in a Field Population of Spadefoot Toads. Copeia (3): 585-591.

SHOEMAKER VH, HILLMAN SS, HILLYARd SD, JACKSON DC, MCCLANAHAN LL, WiTHERS PC, and WYGODA ML (1992) Exchange of water, ions, and respiratory gases in terrestrial amphibians. In: Feder ME, Burggren WW (eds) Environmental physiology of the amphibian. University of Chicago Press, Chicago, 125-150.

SMITH, C.L. (1950). Seasonal changes in blood sugar, fat body, liver glycogen and gonads in the common frog, Rana temporaria. Journal of Experimental Biology (26): 412-429. 
Soares, J.; Duarte, J.; Carvalho, J. and Appell, H.J. (1993) The possible role of intracellular calcium accumulation for the development of immobilization atrophy. International Journal of Sports Medicine (14): 437-439.

SouzA, S.C.R., CARVAlho, J.E., ABE, A.S., Bicudo, J.E.P.W. and BiANCONCINI, M.S.C. (2004) Seasonal metabolic depression, substrate utilization and changes in scaling patterns during the first year cycle of tegu lizards (Tupinambis merianae) Journal of Experimental Biology 207(2): 307-318.

SouzA ReIS, A.C.D. (1976) Climate of Caatinga" Anais da Academia Brasileira de Ciências (48): 325-335.

SYMONDS, B. FRANKLIN, C. and JAMES, R. (2007a) Prolonged aestivation causes little change in skeletal muscle morphology or contractile performance in the anuran Cyclorana alboguttata. Comparative Biochemistry and Physiology Part A (146): S107-S127.

SYMONDS, B. JAMES, R. \& FRANKLIN, C. (2007b) Getting the jump on skeletal muscle disuse atrophy: preservation of contractile performance in aestivating Cyclorana alboguttata (Günther 1867)" The Journal of Experimental Biology (210): 825835.

STOREY, K.B. \& STOREY, J.M. (2004) Metabolic rate depression in animals: transcriptional and translational controls. Biological Reviews (79): 207-233.

StOREY, K. B. (2002) Life in the slow lane: molecular mechanisms of estivation Comparative Biochemistry and Physiology Part A (133): 733-754.

StOREY, K.B. \& STOREY, J.M. (1990) Metabolic rate depression and chemical adaptation in anaerobiosis, hibernation and estivation. The quarterly Review of Biology 65 (2): 154-174.

ST-PIERRE, J. \& BOUTILIER, R.G. (2001) Aerobic capacity of frog skeletal muscle during hibernation. Physiology and Biochemical Zoology 74 (3): 390-397.

TOLEDO R.C. \& JARED C. (1993) Cutaneous adaptations to water-balance in amphibians. Comparative Biochemistry and Physiology Part A (105): 593-608.

TRACY, R.C., ReYNoldS, S.J., McARthuR, L.., TRACY C.R. and ChristiAn, K.A. (2007) Ecology of Aestivation in a Cocoon-forming Frog, Cyclorana australis (Hylidae). Copeia (4): 901-912.

TUNNACLIFFE, A. \& LAPINSKI, J. (2003) Resurrecting Van Leeuwenhoek's rotifers: a reappraisal of the role of disaccharides in anhydrobiosis. Philosophical Transactions of the Royal Society B (358): 1755-1771.

VAN BEURDEN, E.K. (1980) Energy metabolism of dormant Australian water-holding frogs (Cyclorana platycefalus) Copeia (4) 787-799. 
WELLS, K. (2007) The Ecology and Behavior of Amphibians. The University of Chicago Press. Chicago.

WELLS, K.D. (2001) The Energetics of Calling in Frogs. In: Anuran Communication RYAN, M.J. (ed). Smithsonian Inst. Press. Washington, pp. 45-60.

Withers, P.C. \& THOMPson, G.G. (2000) Cocoon formation and metabolic depression by the aestivating hylid frogs Cyclorana australis and Cyclorana cultripes (Amphibia: Hylidae). Journal of The Royal Society of Western Australia (83): 39-40.

ZAR, J.H. (1996) Biostatistical Analysis. Prentice-Hall Inc.; Englewood Cliffs, New Jersey. 